\title{
Signal Transduction by Vascular Endothelial Growth Factor Receptors
}

\author{
Sina Koch and Lena Claesson-Welsh \\ Uppsala University, Department of Immunology, Genetics and Pathology, Rudbeck Laboratory, \\ 75185 Uppsala, Sweden \\ Correspondence: lena.welsh@igp.uu.se
}

\begin{abstract}
Vascular endothelial growth factors (VEGFs) are master regulators of vascular development and of blood and lymphatic vessel function during health and disease in the adult. It is therefore important to understand the mechanism of action of this family of five mammalian ligands, which act through three receptor tyrosine kinases (RTKs). In addition, coreceptors like neuropilins (NRPs) and integrins associate with the ligand/receptor signaling complex and modulate the output. Therapeutics to block several of the VEGF signaling components have been developed with the aim to halt blood vessel formation, angiogenesis, in diseases that involve tissue growth and inflammation, such as cancer. In this review, we outline the current information on VEGF signal transduction in relation to blood and lymphatic vessel biology.
\end{abstract}

\section{INTRODUCTION TO RECEPTOR SIGNALING}

JEGF is a designation both for the family of related VEGF polypeptides and for the original, prototype growth factor, which also was identified as vascular permeability factor (VPF) (Senger et al. 1983). Currently the VEGF family is composed of five structurally related factors: VEGFA (the prototype; also denoted VEGFA165), VEGFB, VEGFC, VEGFD and placenta growth factor (PlGF). The VEGF family members are homodimeric polypeptides although naturally occurring heterodimers of VEGFA and PlGF have been described (DiSalvo et al. 1995). The complexity is increased further by alternative splicing ( for VEGFA, VEGFB, and PlGF) and processing (VEGFA, VEGFC, and VEGFD) (Ferrara 2010; Koch et al. 2011).
Thereby, the ability to bind to VEGF receptors, heparan sulfate (HS) and NRPs (Uniewicz and Fernig 2008; Grunewald et al. 2010), is modulated. For example, VEGFA is alternatively spliced to generate VEGFA121, VEGFA145, VEGFA165, and VEGFA189 (numbers indicating the number of amino acid residues in each human polypeptide). Whereas VEGFA121 is freely diffusible and binds to neither NRPs nor HS, VEGFA 165 and VEGFA189 bind to both, resulting in retention on the cell surface or in the extracellular matrix. The role of NRPs will be discussed in some detail below. HS and mast cell-derived heparin modulate VEGF biology in several ways by binding not only VEGF but also receptors, NRPs and potentially additional interacting proteins, thereby creating clusters of signal transducers (Stringer 2006).

Editors: Michael Klagsbrun and Patricia D'Amore

Additional Perspectives on Angiogenesis available at www.perspectivesinmedicine.org

Copyright (C) 2012 Cold Spring Harbor Laboratory Press; all rights reserved; doi: 10.1101/cshperspect.a006502

Cite this article as Cold Spring Harb Perspect Med 2012;2:a006502 
In addition to the "conventional" VEGFA variants, a series of VEGFA splice variants denoted VEGFA(xxx)b bind, but fail to efficiently activate the cognate VEGF receptors and have therefore been described as antiangiogenic (Harper and Bates 2008).

A number of nonvertebrate polypeptides with structural and functional relatedness to the mammalian VEGFs have been identified. These include the parapox virus open reading frame denoted VEGFE (Ogawa et al. 1998) and the snake venom-derived polypeptides denoted VEGFF (Yamazaki et al. 2005).

Several of the VEGF family of ligands and receptors, notably VEGFA, are regulated by hypoxia-inducible factor (HIF) (Germain et al. 2010), leading to increased expression during tissue growth both in health (wound healing, embryonic development) and disease (cancer). In addition, a wide range of other transcription factors and metabolic regulators such as the ETS family of transcription factors (Randi et al. 2009) and reactive oxygen species, ROS, (UshioFukai and Nakamura 2008) modulate the expression levels of VEGFs as well as of the VEGF receptors. The Notch family of ligands and their receptors have received particular attention because of their important role in restricting the formation of new blood vessels in sprouting angiogenesis (see below, VEGFR2 in the Regulation of Angiogenesis), at least in part by regulating the expression levels of VEGF receptors, which in turn regulate expression of the negative regulatory Notch ligand Delta like 4 (Dll4) (see Jakobsson et al. 2009 and references therein).

The different properties of the VEGF family members modulate their biological impact. For example, the restricted diffusion of HSbinding VEGFs affects the spatial distribution of VEGFR signaling and, in addition, it modulates signaling in a qualitative manner (e.g., by differential engagement of coreceptors such as integrins [Chen et al. 2010]). Moreover, VEGF is produced by most parenchymal cells and acts in a paracrine manner on adjacent endothelial cells (ECs). However, autocrine VEGF has been proposed to be essential for endothelial cell survival. Analyses of recombinant mice specifically lacking EC-produced VEGF indicate that paracrine VEGF may not compensate for autocrine VEGF (Lee et al. 2007).

VEGFs act through three structurally related VEGF receptor tyrosine kinases, denoted VEGFR1 (Flt1), VEGFR2 (Flk1), and VEGFR3 (Flt4) (Fig. 1). The receptors show an overlapping but distinct expression pattern. The continuously increased sensitivity of reagents and detection methods show that there is a wider expression range of the VEGF receptors than initially anticipated. However, there is still an overall pattern of VEGFR1 expression in monocytes and macrophages, VEGFR2 in vascular endothelial cells, and VEGFR3 in lymphatic endothelial cells.

Binding of VEGF to its cognate VEGF receptor in cis or trans (e.g., by binding HS proteoglycans [HSPGs] on adjacent cells [Jakobsson et al. 2006]) induces receptor homo- or heterodimerization. The consequent change in receptor conformation leads to exposure of the ATP-binding site in the intracellular kinase domain, kinase activation and auto- or transphosphorylation of tyrosine residues on the receptor dimer itself as well as on downstream signal transducers. Tyrosine phosphorylation is strictly regulated by internalization and degradation (see below, Integrins in Modulation of VEGFR Signaling) or by dephosphorylation through phosphotyrosine phosphatases (PTPs), such as density enhanced phosphatase 1 (DEP1), vascular endothelial PTP (VEPTP), SRC Homology 2 (SH2) domain PTP (SHP2), and PTP1B (Kappert et al. 2005). Phosphorylated tyrosine residues and amino acid residues carboxy-terminal of the phosphotyrosine create binding sites for intracellular signaling mediators with SH2 domains, allowing formation of signaling chains. Ultimately, these activation cascades result in the establishment of biological responses such as cell proliferation, migration and arrangement in three dimensions (3D) to form a vascular tube.

\section{VEGFR1 SIGNALING}

VEGFR1 signaling and biology appears more elusive than that of other VEGFRs. VEGFR1 is widely expressed, and its kinase activity is 


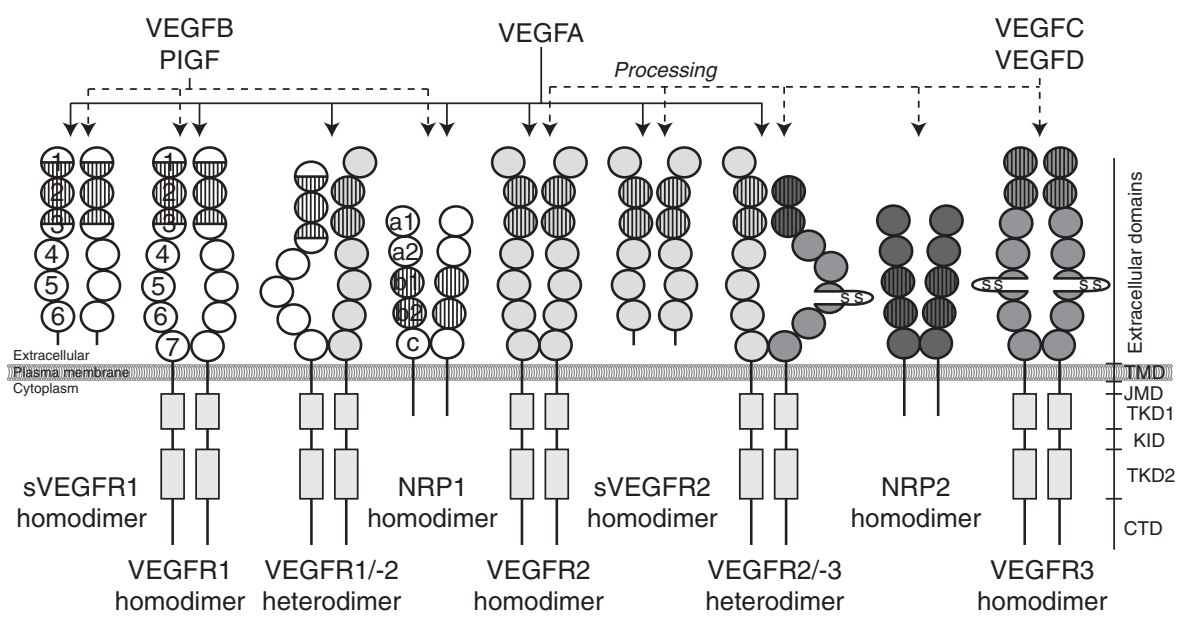

Figure 1. VEGF binding specificities and VEGFR signaling complexes. Five vascular endothelial growth factors, VEGFA, VEGFB, VEGFC, VEGFD, and PIGF, bind with different affinities to three VEGF receptor tyrosine kinases (VEGFR) and two NRP coreceptors initiating homo- and heterodimer formation. Proteolytic processing of VEGFC and VEGFD allows binding to VEGFR2. Extracellular domains of VEGFRs and NRPs involved in VEGF binding are indicated by hatched circles. PlGF, placenta growth factor; sVEGFR1, soluble VEGFR1; sVEGFR2, soluble VEGFR2; TMD, transmembrane domain; JMD, juxtamembrane domain; TKD1, ATP binding domain; KID, kinase insert domain; TKD2, phosphotransferase domain; CTD, carboxy-terminal domain.

poor and not required for endothelial cell function. An important role for VEGFR1 is in negative regulation of VEGFR2 biology, by binding VEGF, and in regulation of monocyte migration during inflammation. Moreover, the different VEGFR1 ligands have quite distinct functions, such as transport of fatty acids and regulation of pathological angiogenesis.

VEGFR1 (alternatively denoted Fms-like tyrosine kinase 1, Flt1, in the mouse) binds VEGFA, VEGFB, and PIGF (Fig. 1). Binding is dependent on extracellular Immunoglobulin (Ig)-like loops 2 and 3 of VEGFR1 (Wiesmann et al. 1997). VEGFR1 exists as a full-length form and an alternatively spliced, soluble form (sFlt1) (Kendall and Thomas 1993). Full-length and soluble VEGFR1 both bind VEGFA with higher affinity than does VEGFR2. Binding of VEGFA to VEGFR1 may therefore prevent activation of VEGFR2. Consequently, sFlt1 has been implicated as a negative regulator of angiogenesis (e.g., in maintenance of corneal avascularity [Ambati et al. 2006]). Moreover, sFlt1 is expressed in the placenta in a regulated manner during gestation (Clark et al. 1998) and has been implicated in the pathogenesis of preeclampsia (Maynard et al. 2003). In particular, a sFlt1 variant denoted sFlt-14 (containing exon 14) accumulates in the circulation of women suffering from preeclampsia (Sela et al. 2008).

Mouse models expressing various recombinant versions of VEGFR1 have been instrumental in revealing its complex biology. Flt $1^{-/-}$ (vegfr $1^{-/-}$) embryos die at embryonic day 9 (E9.0) because of an increased number of endothelial progenitors and formation of disorganized lumen-less vessels (Fong et al. 1995). On the other hand, deletion of the VEGFR1 tyrosine kinase domain in mice is compatible with vascular development (Hiratsuka et al. 1998). Thus, VEGFR1 appears not to be required as a signaling receptor in endothelial cells. Instead, VEGFR1 may serve to capture VEGF to spatially control VEGFR2 signaling and formation of angiogenic sprouts (Kappas et al. 2008).

VEGFR1 kinase activity is only weakly induced by its different ligands. The poor kinase activity may be due to the lack of positive regulatory phosphorylation sites in the kinase activation loop of VEGFR1 (Ito et al. 1998). 
On the other hand, overexpression of VEGFR1 in different tissue culture models showed that most of the intracellular tyrosine residues may be modified by phosphorylation, such as those in position $794,1169,1213,1242,1327$, and 1333 (Fig. 2) (Cunningham et al. 1997; Ito et al. 1998; Yu et al. 2001). Furthermore, the pattern of VEGFR1 tyrosine phosphorylation differs in a ligand-dependent manner (i.e., PlGF, but not other VEGFR1 ligands, may induce phosphorylation of Y1309 [Autiero et al. 2003]).

A range of pathological conditions involving inflammation and recruitment of bone marrow-derived myeloid cells are sensitive to loss of VEGFR1 kinase activity or inhibition of VEGFR1 function. This is true for tumor growth (Hiratsuka et al. 2001), such as glioma (Kerber et al. 2008), as well as metastatic spread of tumors (Kaplan et al. 2006). Other conditions involving inflammation such as rheumatoid arthritis (Murakami et al. 2006), and the early phase poststroke condition (Beck et al. 2010) are also affected by loss of VEGFR1 kinase activity. Thus, at least in part, VEGFR1 regulates endothelial cell function indirectly, through macrophage recruitment (Murakami et al. 2008), followed by deposition of angiogenic growth factors by these cells.

In monocytes, VEGFR1-specific ligands VEGFB and PIGF both induce signaling pathways known to operate downstream of most tyrosine kinase receptors such as extracellular signal-regulated kinase (ERK)/mitogen-activated

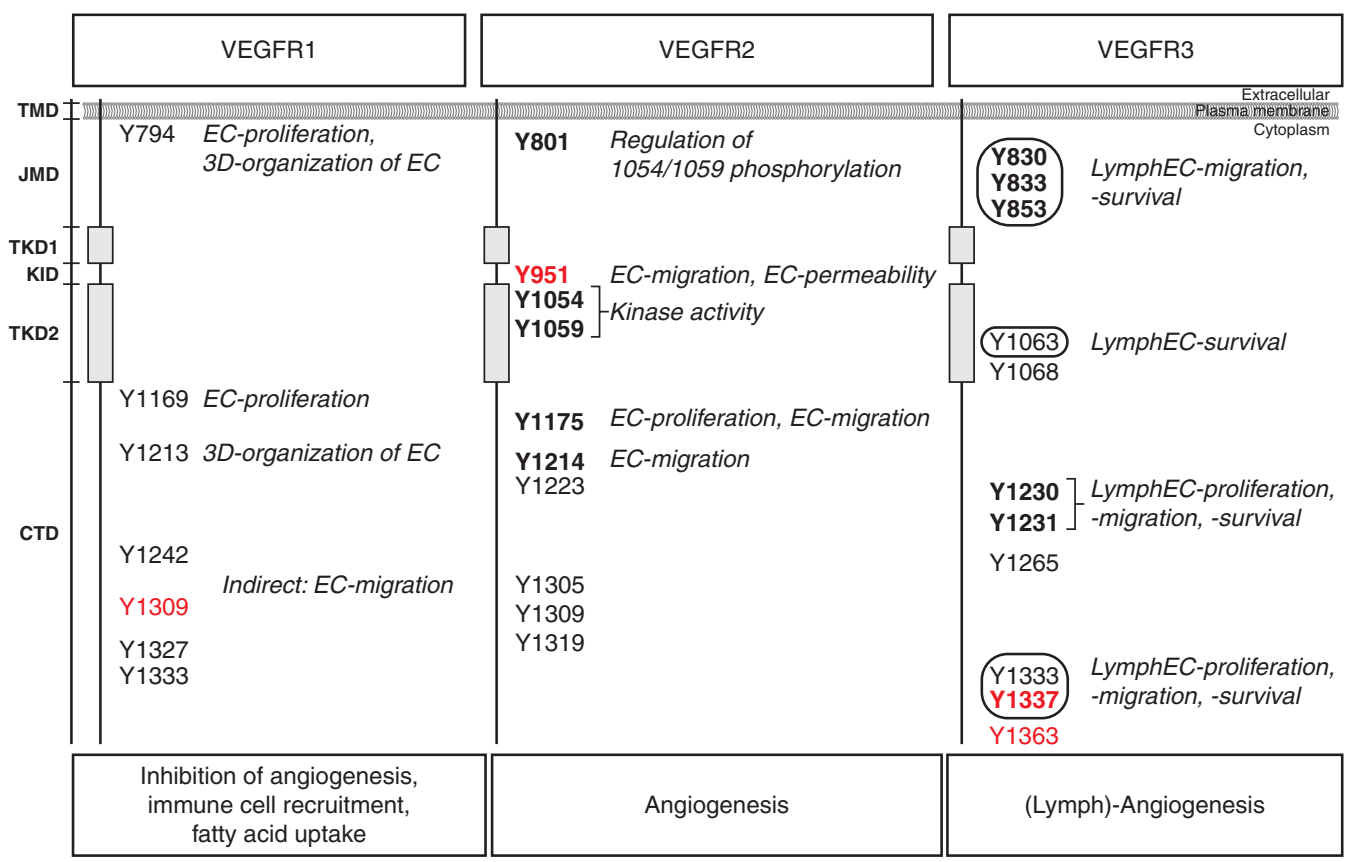

Figure 2. Tyrosine phosphorylation sites in VEGFRs. Intracellular domains of VEGFR monomers are shown schematically with phosphorylated tyrosine residues indicated as $\mathrm{Y}$ followed by a number indicating the position in the amino acid sequence of the receptor. Red numbers indicate selective phosphorylation, i.e., Y1309 in VEGFR1 is phosphorylated on PlGF-, but not VEGF-binding, Y951 in VEGFR2 is phosphorylated in endothelial cells without pericyte contact, and Y1337/Y1363 are phosphorylated in VEGFR3 homodimers, but not in VEGFR2/-3 heterodimers. Tyrosines with identified biological function are bold; tyrosines without known biological function are regular. Encircled residues in VEGFR3 show tyrosines, phosphorylated by extracellular matrix independent of ligand (see text for details and references). Functions are indicated for respective tyrosines in italic. TMD, Transmembrane domain; JMD, juxtamembrane domain; TKD1, ATP binding domain; KID, kinase insert domain; TKD2, phosphotransferase domain; CTD, carboxy-terminal domain; EC, endothelial cell. 
protein kinase (MAPK), phosphoinositide $3^{\prime}$ kinase $(\mathrm{PI} 3 \mathrm{~K}) /$ protein kinase $\mathrm{B}(\mathrm{PKB} / \mathrm{AKT})$, and the stress kinase p38MAPK (Tchaikovski et al. 2008). Which of these VEGFR1-mediated signaling pathways are essential for VEGFR1 biology in vivo, remains to be shown.

Accessory VEGF-binding molecules (i.e., coreceptors, or possibly cell-specific signaling pathways) appear to regulate VEGFR1 biology. Thus, the VEGFR1-specific ligands VEGFB and PlGF have vastly different functions. VEGFB is active on endothelial cells in the heart, where it controls revascularization of the ischemic myocardium (Li et al. 2008). A unique function of VEGFB is to promote fatty acid uptake in endothelial cells, which is critical in organs with high metabolic stress such as the heart (Hagberg et al. 2010). VEGFB-dependent fatty acid transport involves VEGFR1 as well as NRP1. PlGF does not compensate for the loss of VEGFB in fatty acid transport neither in vitro (Hagberg et al. 2010) nor in vivo as evidenced by the different phenotypes of vegfb and plgf gene targeted mice. VEGFB-deficient animals survive development, but display reduced heart size and impaired recovery after cardiac ischemia (Bellomo et al. 2000; Aase et al. 2001). PlGF is also dispensable for embryonic and adult physiological angiogenesis (Carmeliet et al. 2001), but promotes pathological angiogenesis in a number of diseases (see Fischer et al. 2008 for a more detailed review on the properties of PlGF). PlGF also binds to NRP1. Whether additional coreceptors are required in the transduction of VEGFB or PlGF-specific signaling, explaining their distinct biology is not yet clear.

The complexity of VEGFR1 biology is further underscored by the fact that it is expressed by a broad range of cell types, including human tumor cells (Schwartz et al. 2010).

\section{VEGFR2 SIGNALING}

VEGFR2 is the main VEGF receptor on endothelial cells. VEGFR2 is essential for endothelial cell biology during development and in the adult, in physiology and pathology. More is known about VEGFR2 signaling than for the other VEGF receptors. Vascular permeability is an essential in vivo consequence of VEGFR2 activation. Several small-molecular-weight inhibitors of VEGFR2 kinase activity are employed clinically to block pathological angiogenesis in cancer.

VEGFR2 is alternatively designated as KDR (kinase insert domain receptor) in the human and Flk1 (fetal liver kinase-1) in the mouse. VEGFR2 binds VEGFA via its extracellular Ig-like domains 2 and 3, but with a 10-fold lower affinity than VEGFR1 (Fuh et al. 1998; Shinkai et al. 1998). In contrast to VEGFR1, VEGFR2 binds also proteolytically processed VEGFC and VEGFD (Fig. 1) (McColl et al. 2003). VEGFR2 is alternatively spliced to a soluble VEGFR2 (sVEGFR2), which is present in various tissues such as the skin, heart, spleen, kidney, ovary, and in plasma. It binds VEGFC and prevents binding to VEGFR3, consequently inhibiting lymphatic endothelial cell proliferation (Albuquerque et al. 2009).

Vegfr $2^{-/}$mice die at E8.5 from impaired development of hematopoietic and endothelial cells (Shalaby et al. 1995), a phenotype similar to that of the vegfa- mouse (Carmeliet et al. 1996; Ferrara et al. 1996). VEGFR2 is expressed most prominently in vascular endothelial cells and their embryonic precursors, with highest expression levels during embryonic vasculogenesis and angiogenesis (Millauer et al. 1993; Oelrichs et al. 1993; Quinn et al. 1993) and during pathological processes associated with neovascularization such as tumor angiogenesis (Plate et al. 1993; Millauer et al. 1994). VEGFR2 is therefore believed to be the main transducer of VEGFA effects on endothelial cell differentiation, proliferation, migration, and formation of the vascular tube.

Binding of VEGFA to VEGFR2 promotes receptor dimerization which is further stabilized by low-affinity homotypic interactions between membrane-proximal Ig-like domains (Ruch et al. 2007; Yang et al. 2010), allowing trans/autophosphorylation of intracellular tyrosine residues. Major phosphorylation sites are tyrosines Y951 in the kinase insert domain, Y1054, Y1059 within the kinase domain, as well as Y1175 and Y1214 in the carboxy-terminal 
domain (Fig. 2) (Takahashi et al. 2001; Matsumoto et al. 2005). Additional phosphorylation sites in VEGFR2 were identified at 1305, 1309, and 1319 (Matsumoto et al. 2005), but their roles in VEGFR2 biology are as yet unclear. Moreover, the juxtamembrane tyrosine Y801 is phosphorylated when isolated intracellular domains are tested (Solowiej et al. 2009); whether Y801 is phosphorylated in the intact VEGFR2 remains to be shown.

Phosphorylation at Y1054 and Y1059, which are located in the kinase domain activation loop are critical for kinase activity (Kendall et al. 1999). Phosphorylation of these residues may be preceded by autophosphorylation at Y801 (Solowiej et al. 2009).

Phosphorylated Y951 serves as a binding site for the $\mathrm{T}$ cell-specific adapter molecule (TSAd) (Wu et al. 2000; Matsumoto et al. 2005), also denoted VRAP (VEGF receptor associated protein). The Y951 site is phosphorylated on VEGFA stimulation in certain endothelial cells during development as well as in tumor vasculature (Matsumoto et al. 2005), but not in quiescent endothelial cells. Phosphorylation of Y1175 creates a binding site for several signaling mediators like PLC $\gamma$ (Cunningham et al. 1997; Takahashi et al. 2001), and the adapter proteins SHB and SCK (Warner et al. 2000; Holmqvist et al. 2004). Y1175 has also been described to bind SHCA and GRB2, which recruit the nucleotide-exchange factor son of sevenless (SOS) to VEGFR2 (Kroll and Waltenberger 1997; Warner et al. 2000). Phosphorylated Y1214 binds the adapter protein NCK (Lamalice et al. 2006).

The Y1173 site (corresponding to Y1175 in human) is crucial for endothelial and hematopoietic cell development. Mice with a Y1173F knock-in die between E8.5 and E9.5 from lack of endothelial and hematopoietic progenitors (Sakurai et al. 2005), similar to the phenotype of vegfr $2^{-/-}$mice (Shalaby et al. 1995). In contrast, mice with a Y1212F substitution (corresponding to 1214 in humans) are viable and fertile (Sakurai et al. 2005).

A wide range of additional signal transduction mediators have been implicated in VEGFR2 biology as judged from in vitro analyses; often, the in vivo significance remains to be clarified. Intracellular propagation of the signal translates into diverse endothelial cell functions including proliferation, cell survival, transcriptional activation, migration, and vascular leakage. Below is an outline of VEGFR2 signaling implicated in different in vitro or in vivo responses.

\section{VEGFR2 in the Regulation of Angiogenesis}

Endothelial cells need to migrate, proliferate, and organize in three dimensions to create new vessels. Mechanistically, there may be several distinct angiogenic processes (e.g., in development and in different organs). The most rapid angiogenic mechanism, compatible with intact circulation, is the splitting of a preexisting vessel into two new smaller vessels (intussusception) by penetration of smooth muscle cells through the endothelial cell layer (Burri et al. 2004). Intussusception is common in vascular remodeling during development.

Circulating bone marrow-derived endothelial precursor cells (CEPs or EPCs) have been suggested to support the formation of new vessels in adult physiological and pathological angiogenesis. CEPs home to sites of active angiogenesis (e.g., a growing tumor) following a chemotactic cue (Patenaude et al. 2010). However, CEPs do not directly incorporate into the vessel wall but appear to act as accessory cells in close proximity to the endothelium (Grunewald et al. 2006; Kopp et al. 2006; Purhonen et al. 2008). In a third mechanism, denoted sprouting angiogenesis, selected endothelial cells of a preexisting vessel acquire the capacity to invade the surrounding tissue by forming an angiogenic sprout composed of a leading tip cell and trailing stalk cells, which orientate and grow toward the source of a stimulating factor (e.g., VEGFA [Gerhardt and Betsholtz 2005]). The extent of sprouting is negatively regulated by Dll4 and its receptor Notch, which suppress sprouting of endothelial cells neighboring the already initiated sprout (Jakobsson et al. 2009). Sprouting is completed by lumen formation and the establishment of circulation, as soon as two sprouts anastomose, in a process 
Signal Transduction by Vascular Endothelial Growth Factor Receptors

guided by macrophages (Fantin et al. 2010). The newly formed vessel is stabilized by supporting smooth muscle cells and by the deposition of a basement membrane.

VEGFA is a mitogen for endothelial cells and stimulates proliferation through VEGFR2induced activation of the RAS/RAF/ERK/ MAPK pathway (Fig. 3) (Meadows et al. 2001; Zachary 2001). The exact mechanism of VEGFR2-induced RAS activation is not clear; one potential pathway involves protein kinase $\mathrm{C}$ (PKC)-mediated activation of sphingosine kinase (SPK) (Shu et al. 2002). Apart from controlling endothelial proliferation, activation of the RAS signaling chain leads to generation of pleiothropic lipid mediators, the prostaglandins $\left(\mathrm{PGl}_{2}\right)$ via cytoplasmic phospholipase $\mathrm{A}_{2}$ $\left(\mathrm{cPLA}_{2}\right)$ (see Zachary 2001 and references therein). Unlike most other RTKs, VEGFR2 stimulates ERK not via GRB2-SOS-RAS, but via pY1175-dependent phosphorylation of PLC $\gamma$ and subsequent activation of PKCs (Takahashi et al. 2001). Phosphorylated PLC $\gamma$ hydrolyzes the membrane phospholipid phosphatidylinositol (4,5)-bisphosphate $\left(\mathrm{PIP}_{2}\right)$ resulting in accumulation of diacylglycerol (DAG) and inositol 1,4,5-trisphosphate $\left(\mathrm{IP}_{3}\right)$. Generation of $\mathrm{IP}_{3}$ results in increase of intracellular

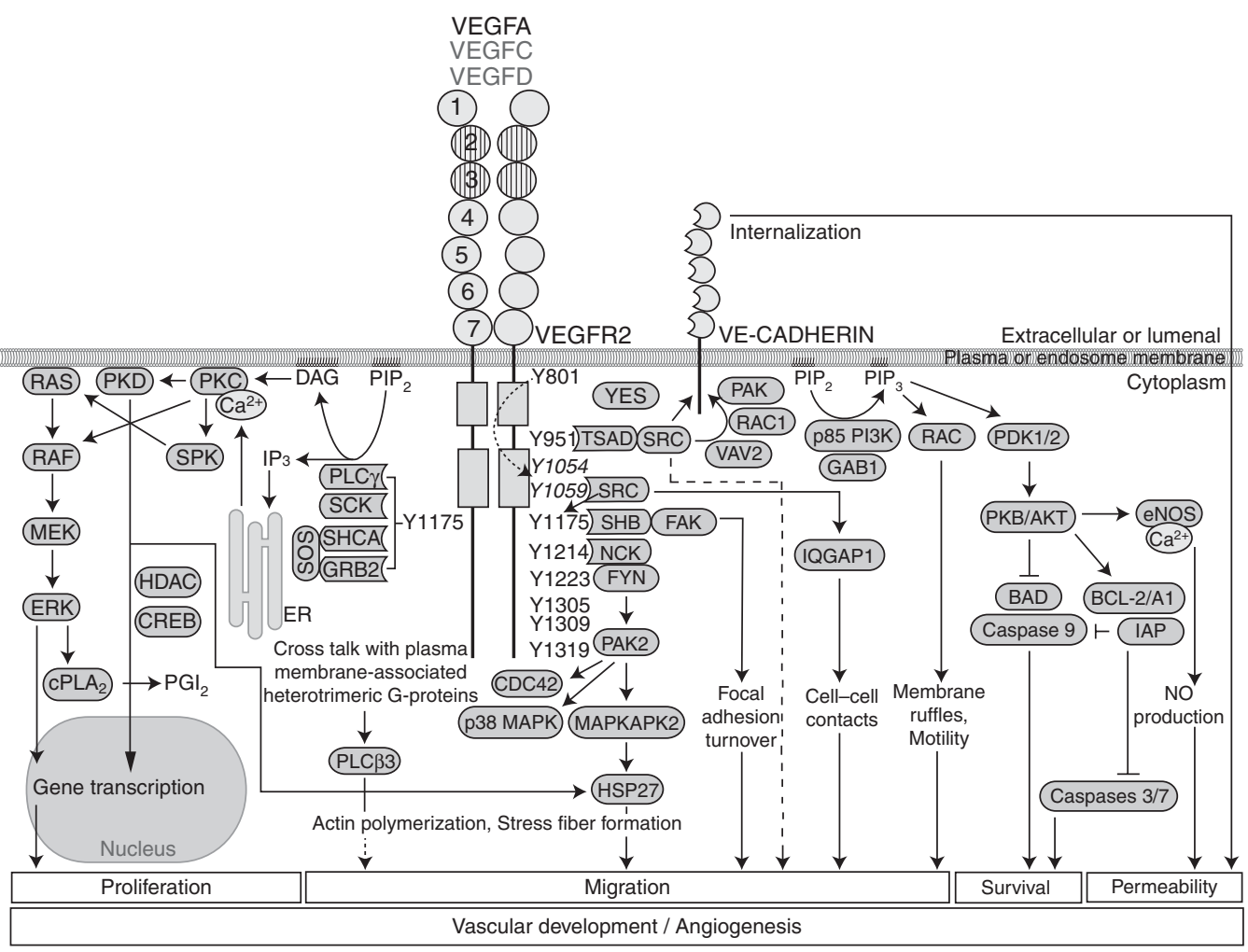

Figure 3. VEGFA165-mediated signal transduction of VEGFR2. The coordinated arrangement of endothelial cells in three dimensions to form and maintain a vascular tube requires endothelial cell proliferation, migration, survival, and permeability. These biological responses are mediated mainly by VEGFA-activated VEGFR2, via a complex network of intracellular signal transduction pathways. On VEGFA-binding to extracellular Ig-like domains 2 and 3 of VEGFR2, signaling molecules bind to respective phosphorylation sites (indicated by numbers) in the intracellular domain of VEGFR2 and activate downstream mediators (ovals) resulting in biological responses such as proliferation, migration, survival and permeability. ER, Endoplasmic reticulum. See text for details. 
calcium $\left[\mathrm{Ca}^{2+}\right]_{\mathrm{i}}$, and DAG activates PKC family members. The PKC isoforms PKCb (Xia et al. 1996; Takahashi et al. 1999), as well as PKCa and $\mathrm{PKCz}$ have been shown to regulate VEGFmediated proliferation (Wellner et al. 1999). PKC activation also results in activation of protein kinase D (PKD) (Wong and Jin 2005), which promotes nuclear translocation of histone deacetylases (HDAC) 5 and 7 (Ha et al. 2008; Wang et al. 2008), followed by phosphorylation of cAMP-response-element binding protein (CREB) as well as heat shock protein 27 (HSP27) (Evans et al. 2008).

PLC $\gamma 1$ is required for VEGF-responsiveness and arterial development in the zebrafish (Lawson et al. 2003). PLC $\gamma 1$ also serves a very important function in mice as plc $\gamma 1$ gene targeting leads to decreased vasculogenesis and erythropoiesis, and embryonic death at E9.0 (Ji et al. 1997; Liao et al. 2002). The phenotype of PLC 1 1-deficient mice mirrors that of mice lacking the PLC $\gamma$-binding site Y1175 in VEGFR2 (Y1173 in the mouse; see above). The loss of binding of the adaptors SHB and SCK may also contribute to the vegfr2 y1173f-like phenotype. SHB is not required for vascular development, but SHB-deficient mice show defects in vessel functionality and impaired tumor growth (Funa et al. 2009). The function of SCK has not yet been assessed using recombinant mouse models.

Migration of endothelial cells is critical for angiogenesis. Endothelial cells move through the protease-degraded basement membrane toward a concentration gradient of VEGFA and other growth factors. Several signal transducers binding to the phosphorylated tyrosines Y951, Y1175, and Y1214 have been implicated in VEGF-induced migration of endothelial cells (Fig. 3).

pY951 binds TSAd (Wu et al. 2000; Matsumoto et al. 2005) and Y951F mutation as well as TSAd knock down prevent VEGFA-dependent actin-reorganization and migration, but not proliferation of endothelial cells. TSAd forms a complex with SRC in a VEGFA-dependent manner (Matsumoto et al. 2005).

pY1175 binds SHB, which becomes phosphorylated in a SRC-dependent manner (Holmqvist et al. 2004). SHB binds to FAK
(Holmqvist et al. 2003), which is tyrosine phosphorylated in VEGF-treated cells (Abu-Ghazaleh et al. 2001), thereby regulating cell attachment and migration (Parsons 2003).

pY1214 allows recruitment of NCK and FYN to VEGFR2. A NCK/FYN complex mediates phosphorylation of $\mathrm{p} 21$-activated protein kinase-2 (PAK-2) and subsequent activation of Cdc42 and p38MAPK (Lamalice et al. 2006). HSP27 is also activated on phosphorylation of Y1214, in a MAPKAPK2-dependent manner (Lamalice et al. 2004).

The docking protein GAB1 interacts with VEGFR2, but the exact tyrosine residue has not yet been identified. Flow shear stress has been shown to stimulate VEGFR2 activation and GAB1 tyrosine phosphorylation in a VEGF-independent manner (Jin et al. 2005). GAB1 contains a binding site for the p85 subunit of PI3K (Laramee et al. 2007). Thereby, VEGF stimulation leads to the generation of $\mathrm{PIP}_{3}$, which in turn activates the GTP-binding RAC, resulting in membrane ruffle formation and cell motility (Cain and Ridley 2009). Furthermore, the actin-binding protein IQGAP1 (IQ motif-containing GTPase activating protein 1) has been implicated in regulation of cell-cell contacts and cell migration (YamaokaTojo et al. 2006).

VEGFR2-induced migration has also been shown to involve signaling via heterotrimeric G-proteins and activation of PLC 33 (Bhattacharya et al. 2009).

\section{Survival}

VEGFR2-PI3K-induced membrane-bound $\mathrm{PIP}_{3}$ production mediates membrane-recruitment and phosphorylation of PKB/AKT by phosphoinositide-dependent kinases 1 and 2 (PDK1 and PDK2) (Fig. 3) (Cantley 2002). AKT phosphorylates BCL-2 associated death promoter (BAD) and caspase 9 and thereby inhibits their apoptotic activity (Cardone et al. 1998). VEGFA also induces the expression of antiapoptotic proteins BCL-2 and A1 (Gerber et al. 1998), as well as the inhibitors of apoptosis (IAP) family members XIAP and survivin, which inhibit the terminal effector caspases 3 
Signal Transduction by Vascular Endothelial Growth Factor Receptors

and 7 (Deveraux et al. 1998; Li et al. 1998). Also, integrins affect the survival of endothelial cells (Fujio and Walsh 1999; see below, Integrins in Modulation of VEGFR Signaling).

\section{Permeability}

VEGFA-induced extravasation of proteins or white blood cells is mediated by VEGFR2 in vivo (Bates and Harper 2003). Two major mechanisms have been implicated in vascular permeability; creation of transcellular endothelial pores, and transient opening of paracellular endothelial junctions (Garrido-Urbani et al. 2008). The signal transduction pathways regulating these events are not clarified. However, VEGF-induced permeability involves endothelial nitric oxide synthase (eNOS)mediated generation of nitric oxide (NO) (Fukumura et al.2001). eNOS is activated either by PLC $\gamma$-dependent $\mathrm{Ca}^{2+}$ influx or AKTmediated phosphorylation at S1179 of eNOS (Fig. 3) (Dimmeler et al. 1999; Fulton et al. 1999). VEGFA-mediated permeability is also dependent on SRC and YES (Eliceiri et al. 1999), which regulate endothelial cell-cell contacts by direct or indirect phosphorylation of the adherens junction protein VE-cadherin (Weis et al. 2004; Wallez et al. 2007). VEGF may also regulate junctional permeability by stimulating endocytosis of VE-cadherin, by sequential activation of SRC-VAV2-RAC and PAK, followed by serine phosphorylation of VE-cadherin (Fig. 4) (Gavard and Gutkind 2006). Furthermore, NRP1 has been implicated in VEGFR2-mediated permeability (Becker et al. 2005).

\section{VEGFR3 SIGNALING}

VEGFC/VEGFR3 are critical regulators of lymphendothelial function. Loss-of-function VEGFR3 mutants in humans cause lymphedema. VEGFR3 is also expressed in vascular endothelial cells and becomes up-regulated during active angiogenesis. VEGFR3 forms homodimers as well as heterodimers with VEGFR2, which modulates the signal output.

VEGFR3 (also denoted Flt4) binds VEGFC and VEGFD. These factors occur in precursor forms, which when processed show increased affinity for binding to both VEGFR2 and VEGFR3 (Joukov et al. 1997; Stacker et al. 1999). VEGFC-binding to VEGFR3 requires extracellular loops 1 and 2 in VEGFR3 (Jeltsch et al. 2006), whereas binding to VEGFR2 involves loops 2 and 3 (Leppanen et al. 2010).

Vegfr3 gene targeted mice die at E10.0-11.0 because of cardiovascular remodeling defects (Dumont et al. 1998). At this stage, VEGFR3 is expressed in vascular endothelial cells. Later in development, VEGFC/VEGFR3 are instrumental in lymphatic development, and expression of VEGFR3 becomes restricted to lymphatic endothelial cells (Kaipainen et al. 1995). However, endothelial cells engaged in active angiogenesis, such as tumor vasculature and endothelial tip cells of angiogenic sprouts in the developing retina express VEGFR3 (Tammela et al. 2008). Also zebrafish VEGFR3 is expressed in the tip cells of developing intersegmental arterial vessels (Siekmann and Lawson 2007).

Patients with certain variants of hereditary lymphedema carry mutations in VEGFR3, resulting in an inactive tyrosine kinase (Irrthum et al. 2000; Karkkainen et al. 2000; Ghalamkarpour et al. 2006). Also, the Chy-mouse mutant whose phenotype is characterized by accumulation of chylous ascites, carries a point mutation in the VEGFR3 tyrosine kinase domain, which renders the kinase enzymatically inactive (Karkkainen et al. 2001). The phenotype of naturally occurring VEGFR3 mutants strongly indicates that, physiologically, VEGFR3 signal transduction is critical in regulation of lymphatic vessel function.

VEGFR3 is also expressed in nonendothelial compartments such as in osteoblasts (Orlandini et al. 2006) and in neuronal progenitors (Le Bras et al. 2006). VEGFC as well as VEGFR3 are furthermore expressed in macrophages (Schmeisser et al. 2006). Whether VEGFR3 is expressed in tumor cells is disputed (Petrova et al. 2008).

Binding of VEGFC/VEGFD to VEGFR3 leads to kinase activation and phosphorylation of at least five carboxy-terminal tyrosine residues in VEGFR3 (Y1230, Y1231, Y1265, 
S. Koch and L. Claesson-Welsh

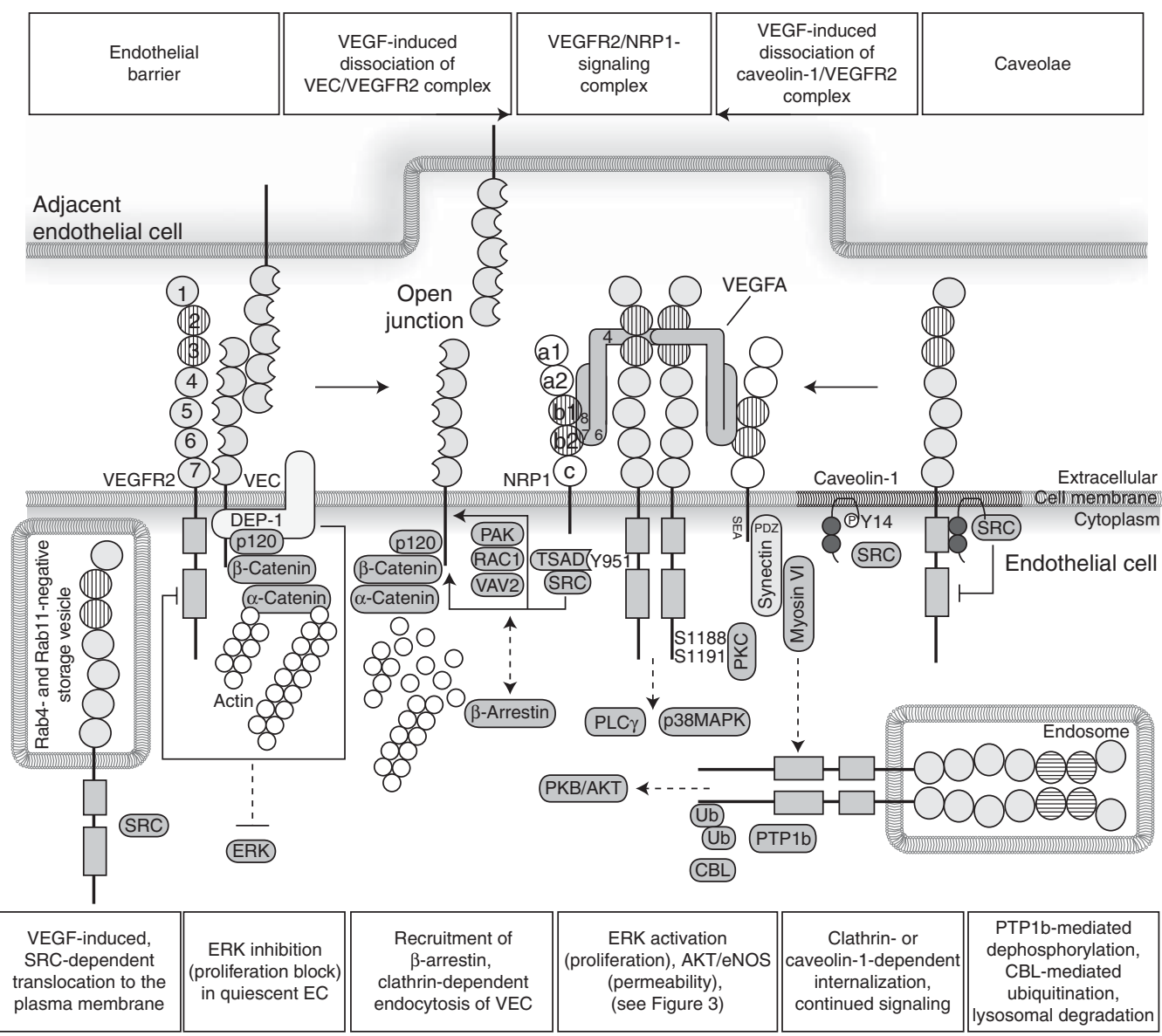

Figure 4. Internalization of VEGFR2. In resting endothelial cells, VE-cadherin prevents internalization of VEGFR2 by physical interaction and recruitment of the DEP-1 phosphatase, which dephosphorylates VEGFR2 to maintain its inactivated state. On VEGF binding, VEGFR2 is released from VE-cadherin or Caveolin-1 followed by activation of signaling cascades and subsequent internalization. VEGFR2 continues to signal from endosomes and eventually becomes ubiquitinated and degraded. See text for details. Note that the exact stoichiometry of the different complexes is unknown. VEC, VE-cadherin.

Y1337, and Y1363) (Fig. 2) (Dixelius et al. 2003). Although not directly shown to be sites of phosphorylation, it is likely that also tyrosine residues Y1063 and Y1068, located in the VEGFR3 kinase domain activation loop, are phosphorylated in response to ligand-binding (Salameh et al. 2005). Y1230 and Y1231 have been implicated in lymphendothelial cell DNA synthesis, migration and apoptosis. Mutation of Y1337 to phenylalanine reduced mitogenic signaling (Salameh et al. 2005). In agreement, Y1337 binds SHC-GRB2, which in turn may induce RAS activity and mitogenic signaling (Fournier et al. 1995).

Another important pathway downstream of VEGFC/VEGFR3 is the PI3K/AKT pathway (Makinen et al. 2001), which may be critical in lymphendothelial cell migration. Migration of lymphendothelial cells in vitro is induced by both VEGFC and the mutant VEGFC156S that binds specifically to VEGFR3 and not to VEGFR2. In vivo, VEGFC-induced migration and sprouting of lymphendothelial precursor cells from restricted regions of the cardinal 
vein is critical for development of the lymphatic system (Karkkainen et al. 2004).

The involvement of the PI3K pathway downstream of VEGFR3 is supported by in vivo data. The gene Pik3r1 encodes three proteins ( p85 $\alpha$, p55 $\alpha$, and p50 $\alpha$ ) that serve as regulatory subunits of class IA PI3Ks. Gene inactivation leading to loss of all protein products of this gene results in chylous ascites, indicative of impaired lymphatic function (Fruman et al. 2000). Furthermore, VEGFC-mediated AKT activation is required for embryonic and adult lymphangiogenesis (Zhou et al. 2010).

An interesting feature of VEGFR3 signal transduction is the consequence of VEGFR2/ VEGFR3 heterodimerization, which changes the pattern of autophosphorylation of VEGFR3 (Dixelius et al. 2003; see below, VEGFR Heterodimerization).

\section{VEGFR SIGNALING COMPLEXES}

The different biological outcomes of VEGFR2mediated signal transduction are modulated by a variety of mechanisms. At the receptor level, complex formation with different receptor dimerization partners, bioavailability of certain ligands, and ligand affinity contribute to shaping the final signal output (Koch et al. 2011).

\section{VEGFR Heterodimerization}

VEGFR1 and -2 bind VEGFA with different affinities (see above). VEGFR1/2 heterodimers are predicted by computational modeling to comprise $10 \%-50 \%$ of the active, signaling VEGF receptor complexes, and to form at the expense of VEGFR1 homodimers when VEGFR2 populations are larger (Mac Gabhann and Popel 2007). There are indications that VEGFAdependent signal transduction of VEGFR1 homodimers is different from VEGFR2 homodimers and VEGFR1/2 heterodimers, for example, with regard to induction of distinct patterns of $\mathrm{Ca}^{2+}$ fluxes (Huang et al. 2001).

Furthermore, VEGFR2 homodimers and VEGFR1/VEGFR2 heterodimers, but not VEGFR1 homodimers, specifically regulate sets of genes including the transcription factor
ETS1, which regulates angiogenesis by inducing target genes such as membrane-degrading matrix metalloproteinases (MMPs), urokinasetype plasminogen activator ( $\mathrm{u}-\mathrm{PA})$, and integrin $\beta 3$ in endothelial cells (Sato 2001).

VEGFA, VEGFC, and VEGFD induce heterodimerization of VEGFR2 and -3. Indeed, VEGFR3 needs to be associated with VEGFR2 to induce at least certain ligand-dependent cellular responses mediated by VEGFC and -D (Alam et al. 2004). In VEGFC-induced heterodimers of VEGFR2 and -3, VEGFR3 is phosphorylated only at three of its five carboxyterminal tyrosine phosphorylation sites. The two most carboxy-terminal tyrosine residues appear not to be accessible for the VEGFR2 kinase (Dixelius et al. 2003). VEGFR2/-3 heterodimers are involved in proliferation and migration of lymphatic endothelial cells and are recruited by VEGFC to leading tip cell filopodia of both developing blood vessels and immature lymphatic sprouts (Nilsson et al. 2010). The subsequent organization into functional capillaries (3D, lumen) may, however, be mediated independently by either of the receptors (Goldman et al. 2007).

\section{VEGFR/NRP Complex Formation}

There are two NRP homologs, NRP1 and NRP2, which are single spanning transmembrane proteins with a small cytoplasmic domain lacking intrinsic catalytic function (Fujisawa et al. 1997). They were first identified as receptors for class 3 semaphorins, a family of soluble molecules with neuronal guidance functions, and implicated in modulating the development of the nervous and vascular systems (Chen et al. 1997; He and Tessier-Lavigne 1997; Kolodkin et al. 1997). Subsequently, NRP1 was shown to bind exon 7-containing VEGFA isoforms such as VEGFA165 (Soker et al. 1998). Thereby a ternary complex is formed wherein VEGFA165 bridges VEGFR2 and NRP1. VEGF121 has been reported to also bind directly to NRP1 but it does not bridge to VEGFR2 (Pan et al. 2007b). NRP1 modulates VEGFR signaling (e.g., by enhancing p38MAPK activation [Kawamura et al. 2008]) leading to 
enhanced migration (Soker et al. 1998) and survival (Wang et al. 2003; Favier et al. 2006) of endothelial cells. In particular, NRP1 has been shown to be essential in VEGFA-induced 3D biology, such as vessel sprouting and branching (Kawamura et al. 2008). NRPs have also been strongly implicated in intracellular trafficking of VEGFR2 by association of the NRP1 carboxy-terminal PDZ-binding domain with the adaptor Synectin (GIPC) (Fig. 4) (Cai and Reed 1999; Wang et al. 2003).

Based on expression patterns and genetic models, NRP1 appears to act primarily as a coreceptor for VEGFR1/2, whereas NRP2 is a coreceptor for VEGFR3 (Fuh et al. 2000; Gluzman-Poltorak et al. 2001). During development, NRP1 is preferentially expressed in arteries, and NRP2 in veins and lymphatics (Herzog et al. 2001; Yuan et al. 2002; Eichmann et al. 2005; Yaniv et al. 2006). Both overexpression and disruption of NRP1 in mice lead to embryonic lethality at E12.5-13.5 caused by either an excess of vessel formation or a range of vascular abnormalities, respectively (Fujisawa and Kitsukawa 1998). NRP2 knockout mice show normal development of arteries and veins but show marked deviations in the development of capillaries and small lymphatics (Yuan et al. 2002). NRP1 and NRP2 double knockout mice display a more severe phenotype and die in utero at E8.5 with a completely avascular yolk sac (Takashima et al. 2002).

Expression of NRP1 in human tumors may correlate with tumor growth, tumor angiogenesis, and invasiveness (Latil et al. 2000; Vanveldhuizen et al. 2003; Wey et al. 2005; Ochiumi et al. 2006). Similarly, NRP2 may also promote tumor growth and metastasis (Dallas et al. 2008; Gray et al. 2008). Treatment with a neutralizing anti-NRP1 antibody reduces angiogenesis and vascular remodeling in vivo and has an additive effect with anti-VEGF antibody therapy in reducing tumor growth and tumor vessel organisation (Pan et al. 2007a). Treatment with a neutralizing anti-NRP2 antibody reduces lymphangiogenesis and functional lymphatics in tumors, while leaving established lymphatics unaffected in vivo. The reduced lymphatic function is accompanied by reduced metastatic spread (Caunt et al. 2008).

NRP1 is ubiquitously expressed and has been detected also on VEGFR2-deficient tumor cells (Gray et al. 2005). VEGF may bridge between tumor cell-expressed NRP1 and VEGFR2 on a nearby endothelial cell. This so-called transactivation may contribute to tumor angiogenesis, in which tumor cells would provide not only VEGFA165 but also NRP1 to attract endothelial cells via VEGFR2 (Soker et al. 2002).

NRP1 may be modified by both heparan and chondroitin sulfation, which may allow indirect binding of a wide range of growth factors to its glycosaminoglycan side chains (Shintani et al. 2006).

\section{Integrins in Modulation of VEGFR Signaling}

Integrins are transmembrane heterodimers that mediate cell-matrix adhesion by specific binding to extracellular matrix, such as collagen, fibronectin, vitronectin, and laminin. VEGFR2 activity is modified by the interaction with certain integrins. For example, in cells plated on vitronectin, VEGF induces complex formation between VEGFR2 and the $\alpha v \beta 3$ integrin. In vivo, the VEGFR2/integrin $\alpha v \beta 3$ interaction is required for active angiogenesis (e.g., in tumors and in healing wounds), as well as in the recruitment of bone marrow-derived cells into angiogenic sites (Mahabeleshwar et al. 2006).

The $\beta 3$ subunit binds VEGFR2 through its extracellular domain and the complex is stabilized by the $\alpha \mathrm{v}$ subunit (Borges et al. 2000; Liu et al. 2009). VEGFR2 autophosphorylation and SRC-mediated phosphorylation of the $\beta 3$ subunit at carboxy-terminal tyrosine residues 747 and 759 (Mahabeleshwar et al. 2007) is crucial for the interaction. VEGFR2/ $\alpha \mathrm{v} \beta 3$ integrin association is important for full VEGFR2 activity, for activation of p38MAPK and focal adhesion kinase (FAK) and for recruitment of the actin-binding vinculin to initiate endothelial cell migration (Pampori et al. 1999; Masson-Gadais et al. 2003; Mahabeleshwar et al. 2008). Integrin $\alpha v \beta 3$ can also associate with NRP1 in a VEGFA-dependent manner and might contribute to the regulation 
Signal Transduction by Vascular Endothelial Growth Factor Receptors

of VEGF-mediated signaling by sequestering NRP1 (Robinson et al. 2009).

VEGFR2 may also associate with the $\beta 1$ integrin in a matrix-bound VEGF-dependent manner, which leads to prolonged phosphorylation of Y1214 of VEGFR2, prolonged phosphorylation of p38MAPK and association of $\beta 1$ integrin with focal adhesions (Chen et al. 2010). In contrast to vitronectin, which positively regulates VEGFR2, collagen I downregulates VEGFA-mediated VEGFR2 activation through recruitment of the phosphatase SHP2 to the activated VEGFR2 (Mitola et al. 2006).

Fibronectin presents binding domains both for integrin $\alpha 5 \beta 1$ and for VEGF. Fibronectin significantly enhances VEGF-induced endothelial cell migration and proliferation, by promoting full VEGFR2 phosphorylation and downstream signal transduction (Wijelath et al. 2006). Furthermore, direct binding of VEGFA, VEGFC, and VEGFD to the integrin $\alpha 9 \beta 1$ contributes to pathologic angiogenesis and lymphangiogenesis (Vlahakis et al. 2007).

Integrins can also mediate phosphorylation of VEGFR3 through SRC at tyrosines 830, 833, $853,1063,1333$, and 1337 in a VEGFC/ VEGFD-independent manner (Fig. 2). This phosphorylation pattern is distinct (although in part overlapping) from that induced by VEGFC and does not depend on the intrinsic kinase activity of VEGFR3. Integrin-mediated VEGFR3 phosphorylation involves the recruitment of adaptor proteins CRKI/II and SHC to VEGFR3, thereby inducing activation of JNK (Galvagni et al. 2010).

\section{INTERNALIZATION AND SIGNALING FROM ENDOSOMES}

Inactive VEGFR2 is associated with caveolin-1, localized in caveolae, which are specialized regions in the plasma membrane (Fig. 4). Upon VEGFA stimulation, VEGFR2 dissociates from caveolin-1, which is a prerequisite for the activation of at least certain pathways downstream of VEGFR2 (Labrecque et al. 2003; Bauer et al. 2005). This is followed by rapid clearance of receptors from the cell surface, or alternatively dephosphorylation by phosphotyrosine phosphatases. The VEGFR2 carboxy-terminal domain contains putative serine phosphorylation sites (S1188 and S1191), which are involved in ligand-dependent down-regulation of the receptor (Singh et al. 2005). VEGFR2 further undergoes ubiquitination and internalization into endosomes, followed by lysosomal degradation of the receptor-ligand complex (Ewan et al. 2006). Internalization is regulated by VE-cadherin (Gavard and Gutkind 2006) and the phosphotyrosine phosphatase DEP-1. The degree of internalization of VEGFR2 in vitro is dependent on cell-cell junctions (Lampugnani et al. 2006) and may be regulated by other receptor tyrosine kinases such as ephrin-B2 in an as yet unclear manner (Sawamiphak et al. 2010). VEGFR2 signaling is not terminated in conjunction with internalization, instead the receptor continues to signal from endosomes (Lampugnani et al. 2006). The NRP-binding adaptor synectin and myosinVI are required to move VEGFR2-containing endosomes away from the plasma membrane, where PTP1b dephosphorylates VEGFR2 specifically at the Y1175 site (Lanahan et al. 2010). Moreover, unlike other RTKs, VEGFR2 seems to be stored in intracellular RAB4- and RAB11-negative vesicles in resting endothelial cells and can be delivered to the plasma membrane upon VEGFA stimulation in a SRC-dependent manner (Gampel et al. 2006). When complexed with NRP1, internalized VEGFR2 can be recycled through Rab5-, Rab4-, and Rab11-positive vesicles. In the absence of NRP1, VEGFR2 is sorted into Rab7-positive vesicles for degradation. Thereby, NRP1 serves to prolong VEGFR2 signaling (Ballmer-Hofer et al. 2011).

Similar to VEGFR2, VEGFR3 internalization is crucial for proangiogenic downstream signaling. VEGFR3 internalization and signaling involving RAC1, AKT, and ERK is regulated by ephrin B2 (Wang et al. 2010).

\section{CONCLUDING REMARKS}

VEGFR signaling has thus far mostly been studied in vitro. The influence of the $3 \mathrm{D}$ context and the possibility that signaling may not be properly recapitulated in a nonendothelial, or 
transformed cell type, calls for more ambitious models. Thus, signaling regulating vascular permeability with transient opening of vascular adherens and tight junctions needs to be studied in vivo. Furthermore, VEGF/VEGFR engage a range of coreceptors that modulate in a qualitative manner, the signal output. Finally, the recent challenges in the application of VEGF-targeted therapies with resistance, rescue (Bergers and Hanahan 2008), and, at least in mouse models, increased invasion and metastasis (Ebos et al. 2009; Paez-Ribes et al. 2009) have shown that we need to learn more about how blood vessels contribute to and are affected by the metabolism of a given tissue.

\section{ACKNOWLEDGMENTS}

The authors acknowledge support from the Uppsala University, the Swedish Cancer Foundation, the Swedish Science Council, and the Wallenberg Foundation for their work.

The authors declare no conflict of interest.

\section{REFERENCES}

Aase K, von Euler G, Li X, Ponten A, Thoren P, Cao R, Cao Y, Olofsson B, Gebre-Medhin S, Pekny M, et al. 2001. Vascular endothelial growth factor-B-deficient mice display an atrial conduction defect. Circulation 104: $358-$ 364.

Abu-Ghazaleh R, Kabir J, Jia H, Lobo M, Zachary I. 2001. Src mediates stimulation by vascular endothelial growth factor of the phosphorylation of focal adhesion kinase at tyrosine 861, and migration and anti-apoptosis in endothelial cells. Biochem J 360: 255-264.

Alam A, Herault JP, Barron P, Favier B, Fons P, DelesqueTouchard N, Senegas I, Laboudie P, Bonnin J, Cassan C, et al. 2004. Heterodimerization with vascular endothelial growth factor receptor-2 (VEGFR-2) is necessary for VEGFR-3 activity. Biochem Biophys Res Commun 324: 909-915.

Albuquerque RJ, Hayashi T, Cho WG, Kleinman ME, Dridi S, Takeda A, Baffi JZ, Yamada K, Kaneko H, Green MG, et al. 2009. Alternatively spliced vascular endothelial growth factor receptor-2 is an essential endogenous inhibitor of lymphatic vessel growth. Nat Med 15: 1023-1030.

Ambati BK, Nozaki M, Singh N, Takeda A, Jani PD, Suthar T, Albuquerque RJ, Richter E, Sakurai E, Newcomb MT, et al. 2006. Corneal avascularity is due to soluble VEGF receptor-1. Nature 443: 993-997.

Autiero M, Waltenberger J, Communi D, Kranz A, Moons L, Lambrechts D, Kroll J, Plaisance S, De Mol M, Bono F, et al. 2003. Role of PlGF in the intra- and intermolecular cross talk between the VEGF receptors Flt1 and Flk1. Nat Med 9: 936-943.

Ballmer-Hofer K, Andersson AE, Ratcliffe LE, Berger P. 2011. Neuropilin-1 promotes VEGFR-2 trafficking through Rab11 vesicles thereby specifying signal output. Blood 118: 816-826.

Bates DO, Harper SJ. 2003. Regulation of vascular permeability by vascular endothelial growth factors. Vascul Pharmacol 39: 225-237.

Bauer PM, Yu J, Chen Y, Hickey R, Bernatchez PN, LooftWilson R, Huang Y, Giordano F, Stan RV, Sessa WC. 2005. Endothelial-specific expression of caveolin-1 impairs microvascular permeability and angiogenesis. Proc Natl Acad Sci 102: 204-209.

Beck H, Raab S, Copanaki E, Heil M, Scholz A, Shibuya M, Deller T, Machein M, Plate KH. 2010. VEGFR-1 signaling regulates the homing of bone marrow-derived cells in a mouse stroke model. J Neuropathol Exp Neurol 69: $168-175$.

Becker PM, Waltenberger J, Yachechko R, Mirzapoiazova T, Sham JS, Lee CG, Elias JA, Verin AD. 2005. Neuropilin-1 regulates vascular endothelial growth factor-mediated endothelial permeability. Circ Res 96: 1257-1265.

Bellomo D, Headrick JP, Silins GU, Paterson CA, Thomas PS, Gartside M, Mould A, Cahill MM, Tonks ID, Grimmond SM, et al. 2000. Mice lacking the vascular endothelial growth factor-B gene (Vegfb) have smaller hearts, dysfunctional coronary vasculature, and impaired recovery from cardiac ischemia. Circ Res 86: E29-38.

Bergers G, Hanahan D. 2008. Modes of resistance to antiangiogenic therapy. Nat Rev Cancer 8: 592-603.

Bhattacharya R, Kwon J, Li X, Wang E, Patra S, Bida JP, Bajzer Z, Claesson-Welsh L, Mukhopadhyay D. 2009. Distinct role of PLC 33 in VEGF-mediated directional migration and vascular sprouting. J Cell Sci 122: 1025-1034.

Borges E, Jan Y, Ruoslahti E. 2000. Platelet-derived growth factor receptor $\beta$ and vascular endothelial growth factor receptor 2 bind to the $\beta 3$ integrin through its extracellular domain. J Biol Chem 275: 39867-39873.

Burri PH, Hlushchuk R, Djonov V. 2004. Intussusceptive angiogenesis: Its emergence, its characteristics, and its significance. Dev Dyn 231: 474-488.

Cai H, Reed RR. 1999. Cloning and characterization of neuropilin-1-interacting protein: A PSD-95/Dlg/ZO-1 domain-containing protein that interacts with the cytoplasmic domain of neuropilin-1. J Neurosci 19: 6519-6527.

Cain RJ, Ridley AJ. 2009. Phosphoinositide 3-kinases in cell migration. Biol Cell 101: 13-29.

Cantley LC. 2002. The phosphoinositide 3-kinase pathway. Science 296: 1655-1657.

Cardone MH, Roy N, Stennicke HR, Salvesen GS, Franke TF, Stanbridge E, Frisch S, Reed JC. 1998. Regulation of cell death protease caspase- 9 by phosphorylation. Science 282: $1318-1321$.

Carmeliet P, Ferreira V, Breier G, Pollefeyt S, Kieckens L, Gertsenstein M, Fahrig M, Vandenhoeck A, Harpal K, Eberhardt C, et al. 1996. Abnormal blood vessel development and lethality in embryos lacking a single VEGF allele. Nature 380: 435-439. 
Carmeliet P, Moons L, Luttun A, Vincenti V, Compernolle V, De Mol M, Wu Y, Bono F, Devy L, Beck H, et al. 2001. Synergism between vascular endothelial growth factor and placental growth factor contributes to angiogenesis and plasma extravasation in pathological conditions. Nat Med 7: 575-583.

Caunt M, Mak J, Liang WC, Stawicki S, Pan Q, Tong RK, Kowalski J, Ho C, Reslan HB, Ross J, et al. 2008. Blocking neuropilin-2 function inhibits tumor cell metastasis. Cancer Cell 13: 331-342.

Chen H, Chedotal A, He Z, Goodman CS, Tessier-Lavigne M. 1997. Neuropilin-2, a novel member of the neuropilin family, is a high affinity receptor for the semaphorins Sema E and Sema IV but not Sema III. Neuron 19: 547-559.

Chen TT, Luque A, Lee S, Anderson SM, Segura T, Iruela-Arispe ML. 2010. Anchorage of VEGF to the extracellular matrix conveys differential signaling responses to endothelial cells. J Cell Biol 188: 595-609.

Clark DE, Smith SK, He Y, Day KA, Licence DR, Corps AN, Lammoglia R, Charnock-Jones DS. 1998. A vascular endothelial growth factor antagonist is produced by the human placenta and released into the maternal circulation. Biol Reprod 59: 1540-1548.

Cunningham SA, Arrate MP, Brock TA, Waxham MN. 1997. Interactions of FLT- 1 and KDR with phospholipase $C \gamma$ : Identification of the phosphotyrosine binding sites. Biochem Biophys Res Commun 240: 635-639.

Dallas NA, Gray MJ, Xia L, Fan F, van Buren G, 2nd Gaur, P., Samuel S, Lim SJ, Arumugam T, Ramachandran V, et al. 2008. Neuropilin-2-mediated tumor growth and angiogenesis in pancreatic adenocarcinoma. Clin Cancer Res 14: $8052-8060$.

Deveraux QL, Roy N, Stennicke HR, Van Arsdale T, Zhou Q, Srinivasula SM, Alnemri ES, Salvesen GS, Reed JC. 1998. IAPs block apoptotic events induced by caspase- 8 and cytochrome $\mathrm{c}$ by direct inhibition of distinct caspases. EMBO J 17: 2215-2223.

Dimmeler S, Fleming I, Fisslthaler B, Hermann C, Busse R, Zeiher AM. 1999. Activation of nitric oxide synthase in endothelial cells by Akt-dependent phosphorylation. Nature 399: 601-605.

DiSalvo J, Bayne ML, Conn G, Kwok PW, Trivedi PG, Soderman DD, Palisi TM, Sullivan KA, Thomas KA. 1995. Purification and characterization of a naturally occurring vascular endothelial growth factor: Placenta growth factor heterodimer. J Biol Chem 270: 7717-7723.

Dixelius J, Makinen T, Wirzenius M, Karkkainen MJ, Wernstedt C, Alitalo K, Claesson-Welsh L. 2003. Ligandinduced vascular endothelial growth factor receptor-3 (VEGFR-3) heterodimerization with VEGFR-2 in primary lymphatic endothelial cells regulates tyrosine phosphorylation sites. J Biol Chem 278: 40973-40979.

Dumont DJ, Jussila L, Taipale J, Lymboussaki A, Mustonen T, Pajusola K, Breitman M, Alitalo K. 1998. Cardiovascular failure in mouse embryos deficient in VEGF receptor-3. Science 282: 946-949.

Ebos JM, Lee CR, Cruz-Munoz W, Bjarnason GA, Christensen JG, Kerbel RS. 2009. Accelerated metastasis after short-term treatment with a potent inhibitor of tumor angiogenesis. Cancer Cell 15: 232-239.
Eichmann A, Makinen T, Alitalo K. 2005. Neural guidance molecules regulate vascular remodeling and vessel navigation. Genes Dev 19: 1013-1021.

Eliceiri BP, Paul R, Schwartzberg PL, Hood JD, Leng J, Cheresh DA. 1999. Selective requirement for Src kinases during VEGF-induced angiogenesis and vascular permeability. Mol Cell 4: 915-924.

Evans IM, Britton G, Zachary IC. 2008. Vascular endothelial growth factor induces heat shock protein (HSP) 27 serine 82 phosphorylation and endothelial tubulogenesis via protein kinase D and independent of pp38 kinase. Cell Signal 20: 1375-1384.

Ewan LC, Jopling HM, Jia H, Mittar S, Bagherzadeh A, Howell GJ, Walker JH, Zachary IC, Ponnambalam S. 2006. Intrinsic tyrosine kinase activity is required for vascular endothelial growth factor receptor 2 ubiquitination, sorting and degradation in endothelial cells. Traffic 7: 1270-1282.

Fantin A, Vieira JM, Gestri G, Denti L, Schwarz Q, Prykhozhij S, Peri F, Wilson SW, Ruhrberg C. 2010. Tissue macrophages act as cellular chaperones for vascular anastomosis downstream of VEGF-mediated endothelial tip cell induction. Blood 116: 829-840.

Favier B, Alam A, Barron P, Bonnin J, Laboudie P, Fons P, Mandron M, Herault JP, Neufeld G, Savi P, et al. 2006. Neuropilin-2 interacts with VEGFR-2 and VEGFR-3 and promotes human endothelial cell survival and migration. Blood 108: 1243-1250.

Ferrara N. 2010. Binding to the extracellular matrix and proteolytic processing: Two key mechanisms regulating vascular endothelial growth factor action. Mol Biol Cell 21: $687-690$.

Ferrara N, Carver-Moore K, Chen H, Dowd M, Lu L, O’Shea KS, Powell-Braxton L, Hillan KJ, Moore MW. 1996. Heterozygous embryonic lethality induced by targeted inactivation of the VEGF gene. Nature 380: 439-442.

Fischer C, Mazzone M, Jonckx B, Carmeliet P. 2008. FLT1 and its ligands VEGFB and PlGF: Drug targets for antiangiogenic therapy? Nat Rev Cancer 8: 942-956.

Fong GH, Rossant J, Gertsenstein M, Breitman ML. 1995. Role of the Flt-1 receptor tyrosine kinase in regulating the assembly of vascular endothelium. Nature 376: 66-70.

Fournier E, Dubreuil P, Birnbaum D, Borg JP. 1995. Mutation at tyrosine residue 1337 abrogates ligand-dependent transforming capacity of the FLT4 receptor. Oncogene 11: 921-931.

Fruman DA, Mauvais-Jarvis F, Pollard DA, Yballe CM, Brazil D, Bronson RT, Kahn CR, Cantley LC. 2000. Hypoglycaemia, liver necrosis and perinatal death in mice lacking all isoforms of phosphoinositide 3-kinase pp85 $\alpha$. Nat Genet 26: 379-382.

Fuh G, Li B, Crowley C, Cunningham B, Wells JA. 1998. Requirements for binding and signaling of the kinase domain receptor for vascular endothelial growth factor. J Biol Chem 273: 11197-11204.

Fuh G, Garcia KC, de Vos AM. 2000. The interaction of neuropilin-1 with vascular endothelial growth factor and its receptor flt-1. J Biol Chem 275: 26690-26695.

Fujio Y, Walsh K. 1999. Akt mediates cytoprotection of endothelial cells by vascular endothelial growth factor 
in an anchorage-dependent manner. J Biol Chem 274: $16349-16354$.

Fujisawa H, Kitsukawa T. 1998. Receptors for collapsin/semaphorins. Curr Opin Neurobiol 8: 587-592.

Fujisawa H, Kitsukawa T, Kawakami A, Takagi S, Shimizu M, Hirata T. 1997. Roles of a neuronal cell-surface molecule, neuropilin, in nerve fiber fasciculation and guidance. Cell Tissue Res 290: 465-470.

Fukumura D, Gohongi T, Kadambi A, Izumi Y, Ang J, Yun CO, Buerk DG, Huang PL, Jain RK. 2001. Predominant role of endothelial nitric oxide synthase in vascular endothelial growth factor-induced angiogenesis and vascular permeability. Proc Natl Acad Sci 98: 2604-2609.

Fulton D, Gratton JP, McCabe TJ, Fontana J, Fujio Y, Walsh K, Franke TF, Papapetropoulos A, Sessa WC. 1999. Regulation of endothelium-derived nitric oxide production by the protein kinase Akt. Nature 399: 597-601.

Funa NS, Kriz V, Zang G, Calounova G, Akerblom B, Mares J, Larsson E, Sun Y, Betsholtz C, Welsh M. 2009. Dysfunctional microvasculature as a consequence of $S h b$ gene inactivation causes impaired tumor growth. Cancer Res 69: $2141-2148$.

Galvagni F, Pennacchini S, Salameh A, Rocchigiani M, Neri F, Orlandini M, Petraglia F, Gotta S, Sardone GL, Matteucci G, et al. 2010. Endothelial cell adhesion to the extracellular matrix induces c-Src-dependent VEGFR-3 phosphorylation without the activation of the receptor intrinsic kinase activity. Circ Res 106: 1839-1848.

Gampel A, Moss L, Jones MC, Brunton V, Norman JC, Mellor H. 2006. VEGF regulates the mobilization of VEGFR2/KDR from an intracellular endothelial storage compartment. Blood 108: 2624-2631.

Garrido-Urbani S, Bradfield PF, Lee BP, Imhof BA. 2008. Vascular and epithelial junctions: A barrier for leucocyte migration. Biochem Soc Trans 36: 203-211.

Gavard J, Gutkind JS. 2006. VEGF controls endothelial-cell permeability by promoting the $\beta$-arrestin-dependent endocytosis of VE-cadherin. Nat Cell Biol 8: 1223-1234.

Gerber HP, McMurtrey A, Kowalski J, Yan M, Keyt BA, Dixit V, Ferrara N. 1998. Vascular endothelial growth factor regulates endothelial cell survival through the phosphatidylinositol 3 -kinase/Akt signal transduction pathway. Requirement for Flk-1/KDR activation. J Biol Chem 273: 30336-30343.

Gerhardt H, Betsholtz C. 2005. How do endothelial cells orientate? Exs 94: 3-15.

Germain S, Monnot C, Muller L, Eichmann A. 2010 Hypoxia-driven angiogenesis: Role of tip cells and extracellular matrix scaffolding. Curr Opin Hematol 17: 245-251.

Ghalamkarpour A, Morlot S, Raas-Rothschild A, Utkus A, Mulliken JB, Boon LM, Vikkula M. 2006. Hereditary lymphedema type I associated with VEGFR3 mutation: the first de novo case and atypical presentations. Clin Genet 70: 330-335.

Gluzman-Poltorak Z, Cohen T, Shibuya M, Neufeld G. 2001. Vascular endothelial growth factor receptor- 1 and neuropilin-2 form complexes. J Biol Chem 276: 18688-18694.

Goldman J, Rutkowski JM, Shields JD, Pasquier MC, Cui Y, Schmokel HG, Willey S, Hicklin DJ, Pytowski B, Swartz MA. 2007. Cooperative and redundant roles of VEGFR-2 and VEGFR-3 signaling in adult lymphangiogenesis. FASEB J 21: 1003-1012.

Gray MJ, Wey JS, Belcheva A, McCarty MF, Trevino JG, Evans DB, Ellis LM, Gallick GE. 2005. Neuropilin-1 suppresses tumorigenic properties in a human pancreatic adenocarcinoma cell line lacking neuropilin-1 coreceptors. Cancer Res 65: 3664-3670.

Gray MJ, Van Buren G, Dallas NA, Xia L, Wang X, Yang AD, Somcio RJ, Lin YG, Lim S, Fan F, et al. 2008. Therapeutic targeting of neuropilin-2 on colorectal carcinoma cells implanted in the murine liver. J Natl Cancer Inst 100: $109-120$.

Grunewald M, Avraham I, Dor Y, Bachar-Lustig E, Itin A, Jung S, Chimenti S, Landsman L, Abramovitch R, Keshet E. 2006. VEGF-induced adult neovascularization: Recruitment, retention, and role of accessory cells. Cell 124: $175-189$.

Grunewald FS, Prota AE, Giese A, Ballmer-Hofer K. 2010. Structure-function analysis of VEGF receptor activation and the role of coreceptors in angiogenic signaling. Biochim Biophys Acta 1804: 567-580.

Ha CH, Wang W, Jhun BS, Wong C, Hausser A, Pfizenmaier K, McKinsey TA, Olson EN, Jin ZG. 2008. Protein kinase D-dependent phosphorylation and nuclear export of histone deacetylase 5 mediates vascular endothelial growth factor-induced gene expression and angiogenesis. J Biol Chem 283: 14590-14599.

Hagberg CE, Falkevall A, Wang X, Larsson E, Huusko J, Nilsson I, van Meeteren LA, Samen E, Lu L, Vanwildemeersch $\mathrm{M}$, et al. 2010. Vascular endothelial growth factor B controls endothelial fatty acid uptake. Nature 464: 917-921.

Harper SJ, Bates DO. 2008. VEGF-A splicing: The key to anti-angiogenic therapeutics? Nat Rev Cancer 8: 880887.

He Z, Tessier-Lavigne M. 1997. Neuropilin is a receptor for the axonal chemorepellent Semaphorin III. Cell 90: 739-751.

Herzog Y, Kalcheim C, Kahane N, Reshef R, Neufeld G. 2001. Differential expression of neuropilin-1 and neuropilin-2 in arteries and veins. Mech Dev 109: 115-119.

Hiratsuka S, Maru Y, Okada A, Seiki M, Noda T, Shibuya M. 2001. Involvement of Flt-1 tyrosine kinase (vascular endothelial growth factor receptor-1) in pathological angiogenesis. Cancer Res 61: 1207-1213.

Hiratsuka S, Minowa O, Kuno J, Noda T, Shibuya M. 1998. Flt-1 lacking the tyrosine kinase domain is sufficient for normal development and angiogenesis in mice. Proc Natl Acad Sci 95: 9349-9354.

Holmqvist K, Cross M, Riley D, Welsh M. 2003. The Shb adaptor protein causes Src-dependent cell spreading and activation of focal adhesion kinase in murine brain endothelial cells. Cell Signal 15: 171-179.

Holmqvist K, Cross MJ, Rolny C, Hagerkvist R, Rahimi N, Matsumoto T, Claesson-Welsh L, Welsh M. 2004. The adaptor protein shb binds to tyrosine 1175 in vascular endothelial growth factor (VEGF) receptor-2 and regulates VEGF-dependent cellular migration. J Biol Chem 279: 22267-22275.

Huang K, Andersson C, Roomans GM, Ito N, ClaessonWelsh L. 2001. Signaling properties of VEGF receptor-1 and -2 homo- and heterodimers. Int J Biochem Cell Biol 33: $315-324$. 
Irrthum A, Karkkainen MJ, Devriendt K, Alitalo K, Vikkula M. 2000. Congenital hereditary lymphedema caused by a mutation that inactivates VEGFR3 tyrosine kinase. Am J Hum Genet 67: 295-301.

Ito N, Wernstedt C, Engstrom U, Claesson-Welsh L. 1998. Identification of vascular endothelial growth factor receptor-1 tyrosine phosphorylation sites and binding of SH2 domain-containing molecules. J Biol Chem 273: 23410-23418.

Jakobsson L, Kreuger J, Holmborn K, Lundin L, Eriksson I, Kjellen L, Claesson-Welsh L. 2006. Heparan sulfate in trans potentiates VEGFR-mediated angiogenesis. Dev Cell 10: 625-634.

Jakobsson L, Bentley K, Gerhardt H. 2009. VEGFRs and Notch: A dynamic collaboration in vascular patterning. Biochem Soc Trans 37: 1233-1236.

Jeltsch M, Karpanen T, Strandin T, Aho K, Lankinen H, Alitalo K. 2006. Vascular endothelial growth factor (VEGF)/ VEGF-C mosaic molecules reveal specificity determinants and feature novel receptor binding patterns. J Biol Chem 281: 12187-12195.

Ji QS, Winnier GE, Niswender KD, Horstman D, Wisdom R, Magnuson MA, Carpenter G. 1997. Essential role of the tyrosine kinase substrate phospholipase C- $\gamma 1$ in mammalian growth and development. Proc Natl Acad Sci 94: 2999-3003.

Jin ZG, Wong C, Wu J, Berk BC. 2005. Flow shear stress stimulates Gab1 tyrosine phosphorylation to mediate protein kinase $B$ and endothelial nitric-oxide synthase activation in endothelial cells. J Biol Chem 280: 12305-12309.

Joukov V, Sorsa T, Kumar V, Jeltsch M, Claesson-Welsh L, Cao Y, Saksela O, Kalkkinen N, Alitalo K. 1997. Proteolytic processing regulates receptor specificity and activity of VEGF-C. EMBO J 16: 3898-3911.

Kaipainen A, Korhonen J, Mustonen T, van Hinsbergh VW, Fang GH, Dumont D, Breitman M, Alitalo K. 1995. Expression of the fms-like tyrosine kinase 4 gene becomes restricted to lymphatic endothelium during development. Proc Natl Acad Sci 92: 3566-3570.

Kaplan RN, Psaila B, Lyden D. 2006. Bone marrow cells in the 'pre-metastatic niche': Within bone and beyond. Cancer Metastasis Rev 25: 521-529.

Kappas NC, Zeng G, Chappell JC, Kearney JB, Hazarika S, Kallianos KG, Patterson C, Annex BH, Bautch VL. 2008. The VEGF receptor Flt-1 spatially modulates Flk-1 signaling and blood vessel branching. J Cell Biol 181: $847-858$.

Kappert K, Peters KG, Bohmer FD, Ostman A. 2005. Tyrosine phosphatases in vessel wall signaling. Cardiovasc Res 65: 587-598.

Karkkainen MJ, Ferrell RE, Lawrence EC, Kimak MA, Levinson KL, McTigue MA, Alitalo K, Finegold DN. 2000. Missense mutations interfere with VEGFR-3 signalling in primary lymphoedema. Nat Genet 25: 153-159.

Karkkainen MJ, Haiko P, Sainio K, Partanen J, Taipale J, Petrova TV, Jeltsch M, Jackson DG, Talikka M, Rauvala $\mathrm{H}$, et al. 2004. Vascular endothelial growth factor C is required for sprouting of the first lymphatic vessels from embryonic veins. Nat Immunol 5: 74-80.

Karkkainen MJ, Saaristo A, Jussila L, Karila KA, Lawrence EC, Pajusola K, Bueler H, Eichmann A, Kauppinen R, Kettunen MI, et al. 2001. A model for gene therapy of human hereditary lymphedema. Proc Natl Acad Sci 98: 12677-12682.

Kawamura H, Li X, Goishi K, van Meeteren LA, Jakobsson L, Cebe-Suarez S, Shimizu A, Edholm D, Ballmer-Hofer K, Kjellen L, et al. 2008. Neuropilin-1 in regulation of VEGF-induced activation of p38MAPK and endothelial cell organization. Blood 112: 3638-3649.

Kendall RL, Thomas KA. 1993. Inhibition of vascular endothelial cell growth factor activity by an endogenously encoded soluble receptor. Proc Natl Acad Sci 90: 10705-10709.

Kendall RL, Rutledge RZ, Mao X, Tebben AJ, Hungate RW, Thomas KA. 1999. Vascular endothelial growth factor receptor KDR tyrosine kinase activity is increased by autophosphorylation of two activation loop tyrosine residues. J Biol Chem 274: 6453-6460.

Kerber M, Reiss Y, Wickersheim A, Jugold M, Kiessling F, Heil M, Tchaikovski V, Waltenberger J, Shibuya M, Plate $\mathrm{KH}$, et al. 2008. Flt-1 signaling in macrophages promotes glioma growth in vivo. Cancer Res 68: 7342-7351.

Koch S, Tugues S, Li X, Gualandi L, Claesson-Welsh L. 2011. Signal transduction by vascular endothelial growth receptors. Biochem J 437: 169-183.

Kolodkin AL, Levengood DV, Rowe EG, Tai YT, Giger RJ, Ginty DD. 1997. Neuropilin is a semaphorin III receptor. Cell 90: 753-762.

Kopp HG, Ramos CA, Rafii S. 2006. Contribution of endothelial progenitors and proangiogenic hematopoietic cells to vascularization of tumor and ischemic tissue. Curr Opin Hematol 13: 175-181.

Kroll J, Waltenberger J. 1997. The vascular endothelial growth factor receptor KDR activates multiple signal transduction pathways in porcine aortic endothelial cells. J Biol Chem 272: 32521-32527.

Labrecque L, Royal I, Surprenant DS, Patterson C, Gingras D, Beliveau R. 2003. Regulation of vascular endothelial growth factor receptor-2 activity by caveolin-1 and plasma membrane cholesterol. Mol Biol Cell 14: 334-347.

Lamalice L, Houle F, Jourdan G, Huot J. 2004. Phosphorylation of tyrosine 1214 on VEGFR2 is required for VEGF-induced activation of Cdc42 upstream of SAPK2/p38. Oncogene 23: 434-445.

Lamalice L, Houle F, Huot J. 2006. Phosphorylation of Tyr1214 within VEGFR-2 triggers the recruitment of Nck and activation of Fyn leading to SAPK2/p38 activation and endothelial cell migration in response to VEGF. J Biol Chem 281: 34009-34020.

Lampugnani MG, Orsenigo F, Gagliani MC, Tacchetti C, Dejana E. 2006. Vascular endothelial cadherin controls VEGFR-2 internalization and signaling from intracellular compartments. J Cell Biol 174: 593-604.

Lanahan AA, Hermans K, Claes F, Kerley-Hamilton JS, Zhuang ZW, Giordano FJ, Carmeliet P, Simons M. 2010. VEGF receptor 2 endocytic trafficking regulates arterial morphogenesis. Dev Cell 18: 713-724.

Laramee M, Chabot C, Cloutier M, Stenne R, HolgadoMadruga M, Wong AJ, Royal I. 2007. The scaffolding adapter Gab1 mediates vascular endothelial growth factor signaling and is required for endothelial cell migration and capillary formation. J Biol Chem 282: $7758-$ 7769. 
Latil A, Bieche I, Pesche S, Valeri A, Fournier G, Cussenot O, Lidereau R. 2000. VEGF overexpression in clinically localized prostate tumors and neuropilin-1 overexpression in metastatic forms. Int J Cancer 89: 167-171.

Lawson ND, Mugford JW, Diamond BA, Weinstein BM. 2003. phospholipase $C \gamma-1$ is required downstream of vascular endothelial growth factor during arterial development. Genes Dev 17: 1346-1351.

Le Bras B, Barallobre MJ, Homman-Ludiye J, Ny A, Wyns S, Tammela T, Haiko P, Karkkainen MJ, Yuan L, Muriel MP, et al. 2006. VEGF-C is a trophic factor for neural progenitors in the vertebrate embryonic brain. Nat Neurosci 9: $340-348$.

Lee S, Chen TT, Barber CL, Jordan MC, Murdock J, Desai S, Ferrara N, Nagy A, Roos KP, Iruela-Arispe ML. 2007. Autocrine VEGF signaling is required for vascular homeostasis. Cell 130: 691-703.

Leppanen VM, Prota AE, Jeltsch M, Anisimov A, Kalkkinen N, Strandin T, Lankinen H, Goldman A, Ballmer-Hofer K, Alitalo K. 2010. Structural determinants of growth factor binding and specificity by VEGF receptor 2. Proc Natl Acad Sci 107: 2425-2430.

Li F, Ambrosini G, Chu EY, Plescia J, Tognin S, Marchisio PC, Altieri DC. 1998. Control of apoptosis and mitotic spindle checkpoint by survivin. Nature 396: $580-584$.

Li X, Tjwa M, Van Hove I, Enholm B, Neven E, Paavonen K, Jeltsch M, Juan TD, Sievers RE, Chorianopoulos E, et al. 2008. Reevaluation of the role of VEGF-B suggests a restricted role in the revascularization of the ischemic myocardium. Arterioscler Thromb Vasc Biol 28: 1614-1620.

Liao HJ, Kume T, McKay C, Xu MJ, Ihle JN, Carpenter G. 2002. Absence of erythrogenesis and vasculogenesis in Plcg1-deficient mice. J Biol Chem 277: 9335-9341.

Liu Z, Kobayashi K, van Dinther M, van Heiningen SH, Valdimarsdottir G, van Laar T, Scharpfenecker M, Lowik CW, Goumans MJ, Ten Dijke P, et al. 2009. VEGF and inhibitors of TGF $\beta$ type-I receptor kinase synergistically promote blood-vessel formation by inducing $\alpha 5$-integrin expression. J Cell Sci 122: 3294-3302.

Mac Gabhann F, Popel AS. 2007. Dimerization of VEGF receptors and implications for signal transduction: A computational study. Biophys Chem 128: 125-139.

Mahabeleshwar GH, Feng W, Phillips DR, Byzova TV. 2006. Integrin signaling is critical for pathological angiogenesis. J Exp Med 203: 2495-2507.

Mahabeleshwar GH, Feng W, Reddy K, Plow EF, Byzova TV. 2007. Mechanisms of integrin-vascular endothelial growth factor receptor cross-activation in angiogenesis. Circ Res 101: 570-580.

Mahabeleshwar GH, Chen J, Feng W, Somanath PR, Razorenova OV, Byzova TV. 2008. Integrin affinity modulation in angiogenesis. Cell Cycle 7: 335-347.

Makinen T, Veikkola T, Mustjoki S, Karpanen T, Catimel B, Nice EC, Wise L, Mercer A, Kowalski H, Kerjaschki D, et al. 2001. Isolated lymphatic endothelial cells transduce growth, survival and migratory signals via the VEGF-C/ D receptor VEGFR-3. EMBO J 20: 4762-4773.

Masson-Gadais B, Houle F, Laferriere J, Huot J. 2003. Integrin $\alpha v \beta 3$, requirement for VEGFR2-mediated activation of SAPK2/p38 and for Hsp90-dependent phosphorylation of focal adhesion kinase in endothelial cells activated by VEGF. Cell Stress Chaperones 8: 37-52.

Matsumoto T, Bohman S, Dixelius J, Berge T, Dimberg A, Magnusson P, Wang L, Wikner C, Qi JH, Wernstedt C, et al. 2005. VEGF receptor-2 Y951 signaling and a role for the adapter molecule TSAd in tumor angiogenesis. EMBO J 24: 2342-2353.

Maynard SE, Min JY, Merchan J, Lim KH, Li J, Mondal S, Libermann TA, Morgan JP, Sellke FW, Stillman IE, et al. 2003. Excess placental soluble fms-like tyrosine kinase 1 (sFlt1) may contribute to endothelial dysfunction, hypertension, and proteinuria in preeclampsia. J Clin Invest 111: 649-658.

McColl BK, Baldwin ME, Roufail S, Freeman C, Moritz RL, Simpson RJ, Alitalo K, Stacker SA, Achen MG. 2003. Plasmin activates the lymphangiogenic growth factors VEGF-C and VEGF-D. J Exp Med 198: 863-868.

Meadows KN, Bryant P, Pumiglia K. 2001. Vascular endothelial growth factor induction of the angiogenic phenotype requires Ras activation. J Biol Chem 276: 49289-49298.

Millauer B, Wizigmann-Voos S, Schnurch H, Martinez R, Moller NP, Risau W, Ullrich A. 1993. High affinity VEGF binding and developmental expression suggest Flk-1 as a major regulator of vasculogenesis and angiogenesis. Cell 72: 835-846.

Millauer B, Shawver LK, Plate KH, Risau W, Ullrich A. 1994. Glioblastoma growth inhibited in vivo by a dominantnegative Flk-1 mutant. Nature 367: 576-579.

Mitola S, Brenchio B, Piccinini M, Tertoolen L, Zammataro L, Breier G, Rinaudo MT, den Hertog J, Arese M, Bussolino F. 2006. Type I collagen limits VEGFR-2 signaling by a SHP2 protein-tyrosine phosphatase-dependent mechanism 1. Circ Res 98: 45-54.

Murakami M, Iwai S, Hiratsuka S, Yamauchi M, Nakamura K, Iwakura Y, Shibuya M. 2006. Signaling of vascular endothelial growth factor receptor-1 tyrosine kinase promotes rheumatoid arthritis through activation of monocytes/macrophages. Blood 108: 1849-1856.

Murakami M, Zheng Y, Hirashima M, Suda T, Morita Y, Ooehara J, Ema H, Fong GH, Shibuya M. 2008. VEGFR1 tyrosine kinase signaling promotes lymphangiogenesis as well as angiogenesis indirectly via macrophage recruitment. Arterioscler Thromb Vasc Biol 28: 658-664.

Nilsson I, Bahram F, Li X, Gualandi L, Koch S, Jarvius M, Soderberg O, Anisimov A, Kholova I, Pytowski B, et al. 2010. VEGF receptor $2 /-3$ heterodimers detected in situ by proximity ligation on angiogenic sprouts. $E M B O$ 29: $1377-1388$.

Ochiumi T, Kitadai Y, Tanaka S, Akagi M, Yoshihara M, Chayama K. 2006. Neuropilin-1 is involved in regulation of apoptosis and migration of human colon cancer. Int $J$ Oncol 29: 105-116.

Oelrichs RB, Reid HH, Bernard O, Ziemiecki A, Wilks AF. 1993. NYK/FLK-1: A putative receptor protein tyrosine kinase isolated from E10 embryonic neuroepithelium is expressed in endothelial cells of the developing embryo. Oncogene 8: 11-18.

Ogawa S, Oku A, Sawano A, Yamaguchi S, Yazaki Y, Shibuya M. 1998. A novel type of vascular endothelial growth factor, VEGF-E (NZ-7 VEGF), preferentially utilizes KDR/ Flk-1 receptor and carries a potent mitotic activity 
without heparin-binding domain. J Biol Chem 273: 31273-31282.

Orlandini M, Spreafico A, Bardelli M, Rocchigiani M, Salameh A, Nucciotti S, Capperucci C, Frediani B, Oliviero S. 2006. Vascular endothelial growth factor-D activates VEGFR-3 expressed in osteoblasts inducing their differentiation. J Biol Chem 281: 17961-17967.

Paez-Ribes M, Allen E, Hudock J, Takeda T, Okuyama H, Vinals F, Inoue M, Bergers G, Hanahan D, Casanovas O. 2009. Antiangiogenic therapy elicits malignant progression of tumors to increased local invasion and distant metastasis. Cancer Cell 15: 220-231.

Pampori N, Hato T, Stupack DG, Aidoudi S, Cheresh DA, Nemerow GR, Shattil SJ. 1999. Mechanisms and consequences of affinity modulation of integrin $\alpha_{\mathrm{V}} \beta_{3}$ detected with a novel patch-engineered monovalent ligand. J Biol Chem 274: 21609-21616.

Pan Q, Chanthery Y, Liang WC, Stawicki S, Mak J, Rathore N, Tong RK, Kowalski J, Yee SF, Pacheco G, et al. 2007a. Blocking neuropilin-1 function has an additive effect with anti-VEGF to inhibit tumor growth. Cancer Cell 11: $53-67$.

Pan Q, Chathery Y, Wu Y, Rathore N, Tong RK, Peale F, Bagri A, Tessier-Lavigne M, Koch AW, Watts RJ. $2007 \mathrm{~b}$. Neuropilin-1 binds to VEGF121 and regulates endothelial cell migration and sprouting. $J$ Biol Chem 282: 24049-24056.

Parsons JT. 2003. Focal adhesion kinase: The first ten years. J Cell Sci 116: 1409-1416.

Patenaude A, Parker J, Karsan A. 2010. Involvement of endothelial progenitor cells in tumor vascularization. Microvasc Res 79: 217-223.

Petrova TV, Bono P, Holnthoner W, Chesnes J, Pytowski B, Sihto H, Laakkonen P, Heikkila P, Joensuu H, Alitalo K. 2008. VEGFR-3 expression is restricted to blood and lymphatic vessels in solid tumors. Cancer Cell 13: 554-556.

Plate KH, Breier G, Millauer B, Ullrich A, Risau W. 1993. Up-regulation of vascular endothelial growth factor and its cognate receptors in a rat glioma model of tumor angiogenesis. Cancer Res 53: 5822-5827.

Purhonen S, Palm J, Rossi D, Kaskenpaa N, Rajantie I, YlaHerttuala S, Alitalo K, Weissman IL, Salven P. 2008. Bone marrow-derived circulating endothelial precursors do not contribute to vascular endothelium and are not needed for tumor growth. Proc Natl Acad Sci 105: $6620-6625$.

Quinn TP, Peters KG, De Vries C, Ferrara N, Williams LT. 1993. Fetal liver kinase 1 is a receptor for vascular endothelial growth factor and is selectively expressed in vascular endothelium. Proc Natl Acad Sci 90: 7533-7537.

Randi AM, Sperone A, Dryden NH, Birdsey GM. 2009. Regulation of angiogenesis by ETS transcription factors. Biochem Soc Trans 37: 1248-1253.

Robinson SD, Reynolds LE, Kostourou V, Reynolds AR, da Silva RG, Tavora B, Baker M, Marshall JF, Hodivala-Dilke KM. 2009. $\alpha v \beta 3$ integrin limits the contribution of neuropilin-1 to vascular endothelial growth factorinduced angiogenesis. J Biol Chem 284: 33966-33981.

Ruch C, Skiniotis G, Steinmetz MO, Walz T, Ballmer-Hofer K. 2007. Structure of a VEGF-VEGF receptor complex determined by electron microscopy. Nat Struct Mol Biol 14: $249-250$.
Sakurai Y, Ohgimoto K, Kataoka Y, Yoshida N, Shibuya M. 2005. Essential role of Flk-1 (VEGF receptor 2) tyrosine residue 1173 in vasculogenesis in mice. Proc Natl Acad Sci 102: 1076-1081.

Salameh A, Galvagni F, Bardelli M, Bussolino F, Oliviero S. 2005. Direct recruitment of CRK and GRB2 to VEGFR-3 induces proliferation, migration, and survival of endothelial cells through the activation of ERK, AKT, and JNK pathways. Blood 106: 3423-3431.

Sato Y. 2001. Role of ETS family transcription factors in vascular development and angiogenesis. Cell Struct Funct 26: 19-24.

Sawamiphak S, Seidel S, Essmann CL, Wilkinson GA, Pitulescu ME, Acker T, Acker-Palmer A. 2010. Ephrin-B2 regulates VEGFR2 function in developmental and tumour angiogenesis. Nature 465: 487-491.

Schmeisser A, Christoph M, Augstein A, Marquetant R, Kasper M, Braun-Dullaeus RC, Strasser RH. 2006. Apoptosis of human macrophages by Flt- 4 signaling: Implications for atherosclerotic plaque pathology. Cardiovasc Res 71: 774-784.

Schwartz JD, Rowinsky EK, Youssoufian H, Pytowski B, Wu Y. 2010. Vascular endothelial growth factor receptor-1 in human cancer: Concise review and rationale for development of IMC-18F1 (Human antibody targeting vascular endothelial growth factor receptor-1). Cancer 116: $1027-1032$.

Sela S, Itin A, Natanson-Yaron S, Greenfield C, GoldmanWohl D, Yagel S, Keshet E. 2008. A novel human-specific soluble vascular endothelial growth factor receptor 1 : Cell-type-specific splicing and implications to vascular endothelial growth factor homeostasis and preeclampsia. Circ Res 102: 1566-1574.

Senger DR, Galli SJ, Dvorak AM, Perruzzi CA, Harvey VS, Dvorak HF. 1983. Tumor cells secrete a vascular permeability factor that promotes accumulation of ascites fluid. Science 219: 983-985.

Shalaby F, Rossant J, Yamaguchi TP, Gertsenstein M, Wu XF, Breitman ML, Schuh AC. 1995. Failure of blood-island formation and vasculogenesis in Flk-1-deficient mice. Nature 376: 62-66.

Shinkai A, Ito M, Anazawa H, Yamaguchi S, Shitara K, Shibuya M. 1998. Mapping of the sites involved in ligand association and dissociation at the extracellular domain of the kinase insert domain-containing receptor for vascular endothelial growth factor. J Biol Chem 273: 31283-31288.

Shintani Y, Takashima S, Asano Y, Kato H, Liao Y, Yamazaki S, Tsukamoto O, Seguchi O, Yamamoto H, Fukushima T, et al. 2006. Glycosaminoglycan modification of neuropilin-1 modulates VEGFR2 signaling. EMBO J 25: 3045-3055.

Shu X, Wu W, Mosteller RD, Broek D. 2002. Sphingosine kinase mediates vascular endothelial growth factorinduced activation of ras and mitogen-activated protein kinases. Mol Cell Biol 22: 7758-7768.

Siekmann AF, Lawson ND. 2007. Notch signalling and the regulation of angiogenesis. Cell Adh Migr 1: 104-106.

Singh AJ, Meyer RD, Band H, Rahimi N. 2005. The carboxyl terminus of VEGFR-2 is required for PKC-mediated down-regulation. Mol Biol Cell 16: 2106-2118. 
Soker S, Takashima S, Miao HQ, Neufeld G, Klagsbrun M 1998. Neuropilin-1 is expressed by endothelial and tumor cells as an isoform-specific receptor for vascular endothelial growth factor. Cell 92: 735-745.

Soker S, Miao HQ, Nomi M, Takashima S, Klagsbrun M 2002. VEGF165 mediates formation of complexes containing VEGFR-2 and neuropilin-1 that enhance VEGF165-receptor binding. J Cell Biochem 85: 357-368.

Solowiej J, Bergqvist S, McTigue MA, Marrone T, Quenzer T, Cobbs M, Ryan K, Kania RS, Diehl W, Murray BW. 2009. Characterizing the effects of the juxtamembrane domain on vascular endothelial growth factor receptor-2 enzymatic activity, autophosphorylation, and inhibition by axitinib. Biochemistry 48: 7019-7031.

Stacker SA, Stenvers K, Caesar C, Vitali A, Domagala T, Nice E, Roufail S, Simpson RJ, Moritz R, Karpanen T, et al. 1999. Biosynthesis of vascular endothelial growth factor-D involves proteolytic processing which generates non-covalent homodimers. J Biol Chem 274: 3212732136.

Stringer SE. 2006. The role of heparan sulphate proteoglycans in angiogenesis. Biochem Soc Trans 34: 451-453.

Takahashi T, Ueno H, Shibuya M. 1999. VEGF activates protein kinase C-dependent, but Ras-independent Raf-MEK-MAP kinase pathway for DNA synthesis in primary endothelial cells. Oncogene 18: 2221-2230.

Takahashi T, Yamaguchi S, Chida K, Shibuya M. 2001. A single autophosphorylation site on KDR/Flk-1 is essential for VEGF-A-dependent activation of PLC- $\gamma$ and DNA synthesis in vascular endothelial cells. $E M B O J \mathbf{2 0}$ $2768-2778$.

Takashima S, Kitakaze M, Asakura M, Asanuma H, Sanada S, Tashiro F, Niwa H, Miyazaki Ji J, Hirota S, Kitamura Y et al. 2002. Targeting of both mouse neuropilin-1 and neuropilin-2 genes severely impairs developmental yolk sac and embryonic angiogenesis. Proc Natl Acad Sci 99: 3657-3662.

Tammela T, Zarkada G, Wallgard E, Murtomaki A, Suchting S, Wirzenius M, Waltari M, Hellstrom M, Schomber T, Peltonen R, et al. 2008. Blocking VEGFR-3 suppresses angiogenic sprouting and vascular network formation. Nature 454: 656-660.

Tchaikovski V, Fellbrich G, Waltenberger J. 2008. The molecular basis of VEGFR-1 signal transduction pathways in primary human monocytes. Arterioscler Thromb Vasc Biol 28: 322-328.

Uniewicz KA, Fernig DG. 2008. Neuropilins: A versatile partner of extracellular molecules that regulate development and disease. Front Biosci 13: 4339-4360.

Ushio-Fukai M, Nakamura Y. 2008. Reactive oxygen species and angiogenesis: NADPH oxidase as target for cancer therapy. Cancer Lett 266: 37-52.

Vanveldhuizen PJ, Zulfiqar M, Banerjee S, Cherian R, Saxena NK, Rabe A, Thrasher JB, Banerjee SK. 2003. Differential expression of neuropilin-1 in malignant and benign prostatic stromal tissue. Oncol Rep 10: 10671071.

Vlahakis NE, Young BA, Atakilit A, Hawkridge AE, Issaka RB, Boudreau N, Sheppard D. 2007. Integrin $\alpha 9 \beta 1$ directly binds to vascular endothelial growth factor (VEGF)-A and contributes to VEGF-A-induced angiogenesis. J Biol Chem 282: 15187-15196.
Wallez Y, Cand F, Cruzalegui F, Wernstedt C, Souchelnytskyi S, Vilgrain I, Huber P. 2007. Src kinase phosphorylates vascular endothelial-cadherin in response to vascular endothelial growth factor: Identification of tyrosine 685 as the unique target site. Oncogene 26: 1067-1077.

Wang L, Zeng H, Wang P, Soker S, Mukhopadhyay D. 2003. Neuropilin-1-mediated vascular permeability factor/ vascular endothelial growth factor-dependent endothelial cell migration. J Biol Chem 278: 48848-48860.

Wang S, Li X, Parra M, Verdin E, Bassel-Duby R, Olson EN. 2008. Control of endothelial cell proliferation and migration by VEGF signaling to histone deacetylase 7. Proc Natl Acad Sci 105: 7738-7743.

Wang Y, Nakayama M, Pitulescu ME, Schmidt TS, Bochenek ML, Sakakibara A, Adams S, Davy A, Deutsch U, Luthi U, et al. 2010. Ephrin-B2 controls VEGF-induced angiogenesis and lymphangiogenesis. Nature 465: 483-486.

Warner AJ, Lopez-Dee J, Knight EL, Feramisco JR, Prigent SA. 2000. The Shc-related adaptor protein, Sck, forms a complex with the vascular-endothelial-growth-factor receptor KDR in transfected cells. Biochem J 347: 501-509.

Weis S, Shintani S, Weber A, Kirchmair R, Wood M, Cravens A, McSharry H, Iwakura A, Yoon YS, Himes N, et al. 2004. Src blockade stabilizes a Flk/cadherin complex, reducing edema and tissue injury following myocardial infarction. J Clin Invest 113: 885-894.

Wellner M, Maasch C, Kupprion C, Lindschau C, Luft FC, Haller H. 1999. The proliferative effect of vascular endothelial growth factor requires protein kinase $\mathrm{C}-\alpha$ and protein kinase C-zeta. Arterioscler Thromb Vasc Biol 19: $178-185$.

Wey JS, Gray MJ, Fan F, Belcheva A, McCarty MF, Stoeltzing O, Somcio R, Liu W, Evans DB, Klagsbrun M, et al. 2005. Overexpression of neuropilin-1 promotes constitutive MAPK signalling and chemoresistance in pancreatic cancer cells. Br J Cancer 93: 233-241.

Wiesmann C, Fuh G, Christinger HW, Eigenbrot C, Wells JA, de Vos AM. 1997. Crystal structure at 1.7 A resolution of VEGF in complex with domain 2 of the Flt-1 receptor. Cell 91: 695-704.

Wijelath ES, Rahman S, Namekata M, Murray J, Nishimura T, Mostafavi-Pour Z, Patel Y, Suda Y, Humphries MJ, Sobel M. 2006. Heparin-II domain of fibronectin is a vascular endothelial growth factor-binding domain: Enhancement of VEGF biological activity by a singular growth factor/matrix protein synergism. Circ Res 99: 853-860.

Wong C, Jin ZG. 2005. Protein kinase C-dependent protein kinase D activation modulates ERK signal pathway and endothelial cell proliferation by vascular endothelial growth factor. J Biol Chem 280: 33262-33269.

Wu LW, Mayo LD, Dunbar JD, Kessler KM, Ozes ON, Warren RS, Donner DB. 2000. VRAP is an adaptor protein that binds KDR, a receptor for vascular endothelial cell growth factor. J Biol Chem 275: 6059-6062.

Xia P, Aiello LP, Ishii H, Jiang ZY, Park DJ, Robinson GS, Takagi H, Newsome WP, Jirousek MR, King GL. 1996. Characterization of vascular endothelial growth factor's effect on the activation of protein kinase $\mathrm{C}$, its isoforms, and endothelial cell growth. J Clin Invest 98: 2018-2026. 
Signal Transduction by Vascular Endothelial Growth Factor Receptors

Yamaoka-Tojo M, Tojo T, Kim HW, Hilenski L, Patrushev NA, Zhang L, Fukai T, Ushio-Fukai M. 2006. IQGAP1 mediates VE-cadherin-based cell-cell contacts and VEGF signaling at adherence junctions linked to angiogenesis. Arterioscler Thromb Vasc Biol 26: 19911997.

Yamazaki Y, Tokunaga Y, Takani K, Morita T. 2005. C-terminal heparin-binding peptide of snake venom VEGF specifically blocks VEGF-stimulated endothelial cell proliferation. Pathophysiol Haemost Thromb 34: 197-199.

Yang Y, Xie P, Opatowsky Y, Schlessinger J. 2010. Direct contacts between extracellular membrane-proximal domains are required for VEGF receptor activation and cell signaling. Proc Natl Acad Sci 107: 1906-1911.
Yaniv K, Isogai S, Castranova D, Dye L, Hitomi J, Weinstein BM. 2006. Live imaging of lymphatic development in the zebrafish. Nat Med 12: 711-716.

Yuan L, Moyon D, Pardanaud L, Breant C, Karkkainen MJ, Alitalo K, Eichmann A. 2002. Abnormal lymphatic vessel development in neuropilin 2 mutant mice. Development 129: $4797-4806$.

Zachary I. 2001. Signaling mechanisms mediating vascular protective actions of vascular endothelial growth factor. Am J Physiol 280: C1375-C1386.

Zhou F, Chang Z, Zhang L, Hong YK, Shen B, Wang B, Zhang F, Lu G, Tvorogov D, Alitalo K, et al. 2010. Akt/ Protein kinase $\mathrm{B}$ is required for lymphatic network formation, remodeling, and valve development. Am J Pathol 177: $2124-2133$. 


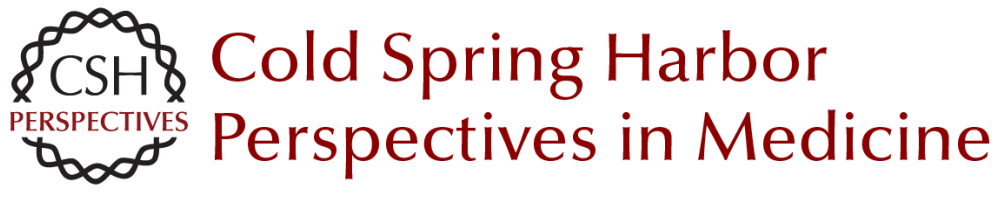

\section{Signal Transduction by Vascular Endothelial Growth Factor Receptors}

Sina Koch and Lena Claesson-Welsh

Cold Spring Harb Perspect Med 2012; doi: 10.1101/cshperspect.a006502 originally published online March 6, 2012

\section{Subject Collection Angiogenesis}

Extracellular Matrix Regulation of Vascular Morphogenesis, Maturation, and Stabilization George E. Davis and Scott S. Kemp

Endothelial Cell-Pericyte Interactions in the Pathogenesis of Cerebral Cavernous Malformations (CCMs) Wang Min and Jenny Huanjiao Zhou

Lymphatic Clearance and Pump Function Jerome W. Breslin

Platelets and (Lymph)angiogenesis Harvey G. Roweth and Elisabeth M. Battinelli

Modeling Brain Vasculature Immune Interactions In Vitro Ruth Lyck, Hideaki Nishihara, Sidar Aydin, et al.

Human Endothelial Colony-Forming Cells Juan M. Melero-Martin

The Beauty and Complexity of Blood Vessel Patterning

Victoria L. Bautch and Yoh-suke Mukouyama

Endothelialitis, Microischemia, and

Intussusceptive Angiogenesis in COVID-19 Steven J. Mentzer, Maximilian Ackermann and Danny Jonigk
Regulation of the Blood-Brain Barrier in Health and Disease Cara C. Rada, Kanako Yuki, Jie Ding, et al.

Targeting Angiogenesis via Resolution of Inflammation

Abigail G. Kelly and Dipak Panigrahy

Notch Signaling in the Vasculature: Angiogenesis and Angiocrine Functions

Sana S. Hasan and Andreas Fischer

Signal Transduction and Gene Regulation in the Endothelium

Michel V. Levesque and Timothy Hla

Buttons and Zippers: Endothelial Junctions in

Lymphatic Vessels

Peter Baluk and Donald M. McDonald

Endothelial Cell Fate Determination: A Top Notch Job in Vascular Decision-Making

L.A. Naiche, Stephanie R. Villa and Jan K. Kitajewski

Leukocyte Trafficking in Lymphatic Vessels Aline Bauer, Hazal Tatliadim and Cornelia Halin

Lymphatic Tissue and Organ Engineering for In Vitro Modeling and In Vivo Regeneration Anna M. Kolarzyk, Gigi Wong and Esak Lee

For additional articles in this collection, see http://perspectivesinmedicine.cshlp.org/cgi/collection/ 